\title{
Centralized Admission and the Student-College Match*†
}

\author{
Cecilia Machado and Christiane Szerman $^{\S}$
}

This Version: March 2017

\begin{abstract}
Decentralized assignments in the education market have been increasingly replaced by centralized ones. However, empirical evidence on these transitions is scarce. This paper examines the adoption of centralized admissions in the Brazilian higher education market. Using rich administrative data, we exploit time variation in the adoption of a clearinghouse across institutions to investigate the impacts on student sorting, migration, and enrollment. We find that institutions under the centralized assignment are able to attract students with substantially higher test scores and that geographical mobility of admitted students increases. While there are no sizable effects on final enrollment rates, the higher turnover rate of seats indicates the search is intensified. Overall, our findings indicate positive impacts of centralization on the college market.
\end{abstract}

Keywords: higher education, centralized matching, college admission, test scores, migration, enrollment.

JEL: D47, I23, I28.

${ }^{*}$ We have benefitted from discussions with Juliano Assunção, Eduardo Azevedo, Braz Camargo, Francisco Costa, Taryn Dinkelman, Fernanda Estevan, Jérémie Gignoux, Matilde Machado, Naercio Menezes Filho, Daniel Monte, Bernard Salanié, Gabriel Ulyssea, conference participants at the 2015 CAEN-EPGE Meeting, the 2015 LACEA, the 2015 NEUDC, the 2015 SBE-ANPEC, the 2016 SOLE, the 2016 North American Summer Meeting of the Econometric Society, the 2016 SAET, the 2016 European Meeting of the Econometric Society, the 2nd International REAP \& SBE Meetings, and seminar participants at EBAPE, FGV, INEP, IPEA and UFRJ. We thank Laura Sant'Anna for excellent research assistance.

${ }^{\dagger}$ We thank Eduardo São Paulo and Instituto Nacional de Pesquisas Educacionais (INEP) for providing access to data. Any opinions and conclusions expressed herein are those of the authors and do not necessarily represent the views of INEP or FGV. All results have been reviewed to ensure that no confidential information is disclosed. All remaining errors are ours.

${ }_{\ddagger}^{\ddagger}$ Corresponding author. Getulio Vargas Foundation (EPGE-FGV) and IZA. E-mail: machadoc@gmail.com

${ }^{\S} \mathrm{CPI}$ /PUC-Rio. E-mail: chriszerman@gmail.com 


\section{Introduction}

Each year, millions of students apply to colleges through a wide variety of mechanisms. In some countries, such as Chile, Turkey, Germany, Taiwan, and the U.K., admissions are entirely centralized, and the allocation of students to colleges is mediated by a clearinghouse. In other countries, such as Japan and the U.S., admissions are decentralized, in the sense that colleges make decisions separately from each other.

In comparison to decentralized markets, it is widely believed that centralization improves coordination, reduces congestion, increases the scope of the market, and improves welfare and matches (Gale and Shapley, 1962; Roth and Xing, 1997; Niederle and Roth, 2003; Abdulkadiroğlu et al., 2005, 2015). These features explain why centralized clearinghouses have long been adopted in many markets. ${ }^{1}$ Recent theoretical research has developed specific frameworks for understanding decentralized markets in college admission and the welfare and efficiency gains of centralization (Chade et al., 2014; Hafalir et al., 2014; Che and Koh, 2016). ${ }^{2}$ Yet, empirical evidence on the benefits of centralized matching in higher education remains surprisingly scarce.

This paper addresses this limitation by exploiting a unique and large-scale policy change in Brazil to study the effects of centralization on college admission. Prior to 2010, each higher education institution selected students based on its own admission exams. Students, in turn, were allowed to apply to as many institutions as they wanted, submitting specific degree choices in each application. A test-score based admission policy meant that institutions offered their seats to the top-scoring candidates. In 2010, the Ministry of Education created the SISU, a centralized clearinghouse that allocates students to federal and state public higher education institutions. ${ }^{3}$ Using scores from a nationwide exam called ENEM, students could submit up to two program choices - where a program corresponds to a degree and institution pair — among the ones made available through the system. Final assignments were made using a deferred acceptance algorithm based on the ENEM score.

\footnotetext{
${ }^{1}$ In the U.S., for example, a centralized clearinghouse called the National Residency Match Program determines the placement of medical students to residency options (Agarwal, 2015). Also, in many cities in the U.S. distinct clearinghouses have been created to assign students to schools in response to research on school choice (Abdulkadiroğlu and Sönmez, 2003).

${ }^{2}$ Chade et al. (2014) develop a decentralized model to understand the role of two application frictions - costly portfolio choices and admission uncertainty — in college admissions. Hafalir et al. (2014) and Che and Koh (2016) characterize the equilibrium outcomes under decentralized admission.

${ }^{3}$ Throughout the paper, we use the terms "public institutions" and "federal and state public institutions" interchangeably.
} 
We exploit the gradual adoption of the clearinghouse across public institutions to compare outcomes within programs before and after centralization, controlling for a battery of fixed effects, state trends, and covariates. Because adoption was not mandatory, we validate our empirical strategy by showing that the timing of adoption was not driven by institution-specific characteristics. Our analysis sample exploits rich information provided by the Brazilian Higher Education Censuses and individual-level data of ENEM test takers, linked together using restricted access identifiers. Our final dataset contains information on all first-year students ever registered in higher education institutions, their demographic characteristics (including places of birth and residence), their ENEM test-scores, and the degrees and institutions they attended.

While most demographic characteristics of admitted students remain similar after centralization, we find sizable effects of centralization on admission test scores. Institutions under the centralized assignment system are able to recruit students that score one-third of a standard deviation higher in the ENEM exam. In addition, we find that enrolled students are more likely to come from a state or municipality that is different from where their program is located. Overall, market integration brought on by centralization increases interstate mobility by 2.5 percentage points, which correspond to a 25 percent increase in the baseline migration rate. These effects are robust to several alternative specifications. Taken together, both findings indicate that centralization expands the scope of the market and improves the student-college match by admitting students with higher scores and from different regions of the country.

Last, we investigate effects on enrollment. The clearinghouse leads to a higher likelihood of an ever-registered student not being enrolled by the end of the first year. Nonetheless, this result is mainly driven by students who cancel their registration before the end of the academic term, possibly indicating that they have opted for a preferred program elsewhere and that the same seat was subsequently occupied by another applicant. We find small effects of a registered student requesting a leave of absence and no effect on the occupancy rate of seats. We interpret these findings as a rise in the turnover rate of seats available in the clearinghouse, with very little impact on enrollments. We note this finding is specific to the Brazilian context, as will be later described.

Our work speaks to three strands in the literature. First, application costs and admission uncertainty are important determinants of students' application decisions (Chade et al., 2014; 
$\mathrm{Fu}, 2014)$. In different contexts, college application has been shown to be sensitive to financial aid and application assistance (Bettinger et al., 2012; Dinkelman and Martínez, 2014), to information about colleges and programs (Carrell and Sacerdote, 2013; Hoxby and Turner, 2013; Oreopoulos and Dunn, 2013), and even to small changes in application costs (Pallais, 2015). In the setting of our study, the centralized system alleviates several costs by providing online information on majors, campus, and institutions, as well as information on admission chances. ${ }^{4}$ Monetary costs are also considerably reduced as one application fee for taking the ENEM exam serves the same purpose as several applications. In addition, the SISU platform is free. The combined reduction of search, time, monetary, and information costs further enhances the reach of the centralized admission system under study.

Second, there is now growing evidence of both under- and overmatch between students and colleges (Dillon and Smith, 2016). The literature has documented that low-income high-achievers undermatch more often than their high-income counterparts because their application decisions are sensitive to information acquired by peers in the same geographical location (Hoxby and Avery, 2014; Hoxby and Turner, 2015). Market scope also plays a relevant role in academic mismatch, which generally results from restricted admission and affirmative action policies (Arcidiacono et al., 2011; Sander and Taylor, 2012; Black et al., 2015; Arcidiacono and Lovenheim, 2016). Our results suggest that market integration improves the matches between students and institutions. Since college quality is strongly associated with college completion rates (Cohodes and Goodman, 2014), improvements in the studentcollege match can have lasting effects on educational attainment and labor market returns of the affected cohorts.

Third, this paper also relates to the literature that studies the effects of centralization and coordination in other markets. Niederle and Roth (2003) find that the implementation of a centralized clearinghouse for gastroenterologists increased mobility by widening the scope of the market. Abdulkadiroğlu et al. (2015) show that the introduction of a coordinated centralized assignment enhances students' willingness to travel, in comparison to the old uncoordinated mechanism, even though daily commutes are costly to school students. Our results are the first to focus on the college market and, specificities apart, are consistent with the existing empirical evidence.

\footnotetext{
${ }^{4}$ In a school choice context, Narita (2016) shows that demand-side frictions affect the gains from centralization. The author suggests that information on school characteristics and updated choices can reduce these frictions.
} 
This paper proceeds as follows. Section 2 describes the Brazilian higher education system and the introduction of the new college clearinghouse. We also discuss the expected effects of centralization on student sorting, migration, and enrollment. Sections 3 and 4 outline the data and the empirical strategy, respectively. Section 5 presents the main results. We conclude in Section 6.

\section{Institutional Context}

\subsection{Higher Education in Brazil}

The Brazilian higher education system consists of 2,368 private and public institutions of distinct characteristics and quality levels. Among them, 298 are public institutions administered by the federal (107 institutions), state (118) or municipal (73) governments. Private institutions are either for-profit or non-profit organizations, and for-profit institutions account for a larger share of the market. Institutions offer bachelor and licentiate degree programs, which take on average 4 to 6 years to complete, and technological degree programs, which last on average 2 to 3 years.

Public institutions do not charge tuition fees in most cases, with the exception of municipal institutions. ${ }^{5}$ They offer a limited number of seats and are generally perceived as having the best and most selective programs, leading to intense competition in admission. ${ }^{6}$ Admissions to private institutions, in contrast, meet a lower standard. Tuition is high on average and imposes a financial burden to low-income families. ${ }^{7}$

Similar to Chile and Norway, students in Brazil choose their majors at the application stage. Admission is exclusively based on entrance exam scores and does not depend on high school GPA or subjective assessments, such as recommendation letters. Each year approximately 3 million first-year students are enrolled in higher education programs (20102014 Higher Education Censuses).

\footnotetext{
${ }^{5}$ The Brazilian Constitution bans tuition fees in public institutions, including those administered at the municipal level. However, some municipal public institutions still charge fees under the argument that they are not entirely financed by public funds. There is an ongoing legal debate on whether tuition can indeed be charged by municipal institutions.

${ }^{6}$ Between 2010 and 2014, the share of seats in public institutions has ranged from 22 to 16 percent (2010-2014 Higher Education Censuses).

${ }^{7}$ Monthly tuition is about 645 reais, equivalent to 89 percent of the 2014 minimum wage (Hoper Educação, 2014).
} 
Prior to 2010, admissions were completely decentralized. Students directly applied to each institution and had to take a specific entrance examination, known as Vestibular. ${ }^{8}$ Students could apply to as many institutions as they wanted, but all applicants to a given institution would take the Vestibular exam at the same date and time. ${ }^{9}$ Only top-scoring applicants to each program were offered a seat. A single student could be admitted to several programs and be enrolled in more than one at the same time. Any remaining vacant seats would be gradually offered to waitlisted applicants according to their rank.

Aiming to improve fair access to public higher education institutions, the Ministry of Education introduced a series of reforms starting in 2008. Most important was the reformulation of the secondary education assessment exam (henceforth "ENEM"), beginning with the 2009 edition, followed by the creation of a centralized admission clearinghouse (henceforth "SISU") in January of 2010.

\subsection{The ENEM exam}

Created in 1998, the ENEM exam was conceived to be a non-mandatory one-day exam to evaluate secondary schooling. Indeed, since its inception, the exam has been widely used in schools' league tables to give information about the quality of secondary schools (Camargo et al., 2014). Prior to its reformulation, the ENEM was regarded as a problemsolving and critical analysis assessment rather than a rigorous curriculum-based examination. It consisted of 63 multiple-choice questions from a range of subjects and a written essay. Perceived as a less rigorous assessment than Vestibular, the ENEM exam was virtually irrelevant for most admission procedures in public institutions, but it was used for admission in many private institutions. ${ }^{10}$

In addition, ENEM scores are used for granting scholarships to low-income students

\footnotetext{
${ }^{8}$ Institutions are free to design their own entrance exams. For example, some institutions select students in two rounds, with a first round based on a multiple choice exam and a second round with written questions specific to the chosen degrees, and an essay. Others have a single-stage exam with scores weighted by major choice.

${ }^{9}$ Vestibular exams are typically scheduled once a year, in the second semester of the year that precedes admission. Since the academic term goes from February to December, the exams are scheduled between October and January. If two or more Vestibular exams are scheduled at the same day and time, only one can be taken.

${ }^{10}$ Very few public institutions adopted the ENEM scores in their admission procedures. Some notable exceptions were UNICAMP, USP, and UNIRIO. ENEM scores have been part of the admission criteria at UNICAMP and USP since 2000 and 2003, respectively. Between 2007 and 2009, UNIRIO allocated half of its seats to admissions using only ENEM scores.
} 
in private institutions through the PROUNI program. ${ }^{11}$ Created in 2004, PROUNI offers fellowships to top-scoring applicants. Cutoff scores depend on the number of available seats in each program. In 2016, more than 328,000 PROUNI scholarships were offered. Since admission to public institutions is highly competitive and uncertain, the large majority of college applicants had great incentive to take the ENEM exam even before its reformulation in 2009.

In 2008, the Ministry of Education announced that the ENEM exam would become more content-based and rigorous to boost its use as the only entrance examination used by higher education institutions, especially public institutions. With 180 multiple-choice questions and a written essay, the new structure resembles the most competitive Vestibular exams. To take the ENEM exam, applicants have to pay a registration fee of approximately 20 USD (or 68 reais in the 2016 edition). In some cases, payment exemption is allowed. The exam is simultaneously taken across the country once a year, at the end of the academic year. Item response theory is also used in the calculation of the final scores to allow for comparability of ENEM scores from 2009 onward.

Although the ENEM exam remains optional to high school students, its reach is remarkable. In 2014, the total number of applicants reached a record high of nearly 8.7 million. The expansion is striking when compared to only 157.221 students registered in its first edition in 1998. Figure 1 illustrates the evolution in the number of test-takers and highlights two jumps. The first, in 2004, is attributed to the creation of the PROUNI program. The second jump, in 2010, is primarily driven by the implementation of the SISU system. ${ }^{12}$

\subsection{The SISU System}

After its reformulation, ENEM scores were gradually incorporated into the admission criteria of many private and public institutions. To facilitate its use exclusively by public

\footnotetext{
${ }^{11}$ In addition to taking the ENEM exam, PROUNI applicants have to comply with one of the following criteria: have had their entire high school education either in public high schools or in private high schools under full scholarship; being disabled; or being a teacher in public schools. Full and partial scholarships are awarded to applicants based on their per capita monthly household income (lower than 1.5 and 3 minimum wages, respectively). Applicants submit their ENEM scores and choices through the PROUNI online platform.

${ }^{12}$ It is important to note that taking the ENEM became required for financial aid application to FIES (Fundo de Financiamento Estudantil) in 2010. However, it was only requested for applicants graduating from high school in the year of application, with no minimum score requirement. By 2015, FIES required all applicants to take the ENEM in the year of application, and a minimum score of 450 points (out of 1000).
} 
and tuition-free institutions, the Ministry of Education created SISU (Sistema de Seleção Unificada) in January of $2010 .^{13}$. SISU is an online platform that allocates students to public institutions and uses ENEM scores as the only metric to rank candidates.

Although SISU was available to all public tuition-free institutions, its adoption was not compulsory. Institutions could decide whether they would offer their seats through SISU and how many seats would be offered for each degree. A few degrees that require very specific skills prior to admission (e.g. Music, Performing Arts, and Visual Arts) could still admit their students through the traditional Vestibular exams, even when their institutions had opted to participate in the SISU system. The Ministry of Education, in turn, encouraged institutions to move to a centralized system by providing them additional monetary transfers. ${ }^{14}$

The number of available seats in SISU is announced at the beginning of each edition, about one month before the start of the academic semesters, January and July. However, the majority of spots are offered in the January opening, even for programs that start in the second semester. Registration is online and free. Only candidates who had taken the ENEM exam in the previous year are able to register on the platform in the current year. The registration period lasts 4 or 5 days. Over that period, applicants can choose up to two ranked degree-institution pairs (hereafter, "programs") from the options offered in the system. The platform also allows for differential competition (and, consequently, differential admission scores) for seats reserved through affirmative action policies.

Admission cutoff scores depend both on the number of available seats and on applicants' preferences. Previews of cutoff scores are made available online for all candidates based on choices registered so far. Candidates can change their choices as many times as they wish while the system is open. Only the last confirmed choice is valid. When the system closes, it assigns applicants to programs through a deferred acceptance algorithm, which has been argued to be a strategy-proof mechanism in similar contexts (Hastings et al., 2013; Kirkeboen et al., 2016). Candidates are accepted to their most preferred program for which they qualify.

\footnotetext{
${ }^{13}$ Another important regulation was enacted in November of 2009 and prohibited two or more seats in public institutions from being occupied by the same student (Law 12.089). Until then, a student could be enrolled in more than one public institution at the same time. Anecdotal evidence suggests that this situation was not unusual. The new regulation aimed to increase the relative availability of seats in public institutions and preceded the creation of SISU.

${ }^{14}$ In 2010, the Ministry of Education created both PNAES and PNAEST, which are programs that guarantee resources for student assistance in state and federal public institutions, respectively. For state public institutions, the transfers were proportional to the number of seats made available through SISU. For federal public institutions, there was no such explicit condition. Because federal institutions are funded by the federal government, alignment with the Ministry of Education is desirable.
} 
The results of the assignment mechanism and the list of admitted candidates are published online. All applicants are informed about their classification on the list. Appendix I provides further details of the system.

By 2008, when the Ministry of Education announced the ENEM reformulation, many institutions were skeptical about its new and selective content and about the practical management of an exam of such importance. However, both ENEM and SISU have built a solid reputation over time, and more institutions increasingly joined the centralized assignment mechanism. In the first year of SISU, 59 out of 178 federal and state public institutions adopted the system. From 2010 to 2014, SISU adoption rapidly increased, both in number of institutions and in number of available seats. ${ }^{15}$

In sum, after 2010, public institutions experienced a broader range of options to admit students. Currently, four non-exclusive admission metrics are available: Vestibular scores only, some combination of ENEM and Vestibular scores, ENEM scores without the SISU platform, and ENEM scores through the SISU platform. ${ }^{16}$

\subsection{Theoretical Discussion}

Before turning to our empirical strategy, which exploits the gradual adoption of SISU across public institutions in Brazil, we discuss the expected first-order effects of centralization on student sorting (measured by test scores), migration, and enrollment.

\subsubsection{Test Scores}

While deviations in academic assortative matching are common in higher education, students' application and enrollment decisions are key drivers of such results. Therefore, rules, regulations and procedures in admissions are critical to enhance competition among applicants, improve the quality of the entering cohort, and reduce college mismatch. Aside from information on admission standards that are made available on SISU, the nearly universal

\footnotetext{
${ }^{15}$ Figures 6 and 7, Appendix II, depict these patterns. In 2010, approximately 25 percent of public institutions joined SISU. More than 64,000 seats were offered in the system. In 2014, about 50 percent of public institutions had adopted SISU and almost 225,000 seats were made available in the system.

${ }^{16}$ In 2014, for example, all federal universities used ENEM scores to select students by joining the SISU system, by incorporating the ENEM score into the overall grade in the Vestibular exams without SISU, or by employing the ENEM score as first phase or bonus for admissions through Vestibular. In January of 2015, only 5 out of 63 federal universities did not select students through SISU.
} 
nature of ENEM-taking also informs students about their own ability and on how admissible they are to selective institutions and degrees (Goodman, 2016).

In a theoretical framework, Che and Koh (2016) analyze the consequences of a centralized college admission that uses a deferred acceptance assignment. The authors show that, although centralized admission leads to efficiency and fairness, it does not necessarily imply that all colleges will be better off. Some colleges may be worse off because they no longer attract some good students they used to get under the decentralized admission process. In a centralized setting, students will be assigned to the best colleges for which they qualify, with no justified envy among them. Cutoff admission scores will exhibit a monotonic pattern and only the top-scoring students will be enrolled.

In the case of SISU, the clearinghouse not only coordinates assignments across participant institutions, but also facilitates the application process for students. Search costs are considerably reduced due to the availability of a friendly interface that gathers information on available majors, institutions, and campus location. ${ }^{17}$ In addition, monetary and time costs are lowered because applicants only need to take one exam serving multiple purposes, instead of bearing many application fees and taking many admission exams. ${ }^{18}$

These combined features are expected to change application decisions and move prices (measured by admission cutoff scores) in the direction of the aggregate and nationwide demand. In the Brazilian case, switching to SISU is only possible for federal and state public institutions, which are perceived as high quality institutions in the country. They are also tuition-free, which allows them to attract students regardless of their income or willingness to pay. Thus, centralization is expected to increase competition and the sorting of admitted students. If seats in public institutions are in high demand, admission scores should increase for them.

\subsubsection{Migration}

Before SISU, public institutions operated in local markets, serving mainly its local population. In most cases, exams were taken near the place in which institutions were located,

\footnotetext{
${ }^{17}$ In the U.S., the Common Application is an example of an online instrument that facilitates the search and college application process.

${ }^{18}$ Pallais (2015) shows that students are sensitive to monetary costs in college application decisions. When they were allowed to send an extra free application, they applied to more colleges and low-income students attended more selective colleges.
} 
which severely limited the geographical scope of applications. Moreover, applicants needed to gather information about the application rules (dates and requirements) on a case-by-case basis. With centralization, the scope of the market increases, allowing public institutions to recruit nationally. While SISU alleviates many geographical barriers, migration in not a foregone conclusion.

Although public institutions are tuition-free, subsistence costs, including room and board, can be sizable in a context in which credit lines and loans are not easily available. An additional factor is the sizable dimension of the country. We empirically investigate which effect dominates.

\subsubsection{Enrollment}

Seats offered by public institutions are in fixed supply. Both before and after SISU, seats are only made available to candidates ranked on the waitlist only after they have been declined by previous occupants. While capacity constraints are met by design, rendering subscription beyond the target impossible, there are still concerns about undersubscription: seats left unoccupied by the end of the academic term are still paid for by public funds.

College quality has lasting effects on persistence. If centralization improves matches, enrollment rates by the end of the first year could increase. In our data, however, enrollment rates of students ever offered a seat are quite high, and it is possible that SISU does not operate on this margin. More interesting is the effect of centralization on the seat turnover rate, which is measured as the likelihood of an ever-existing registration being canceled (in this case, the seat is left vacant for the next top-scoring applicant). As search costs decrease, we expect turnover to increase.

\section{Data}

In this paper, we use two annual administrative datasets, the Brazilian Higher Education Census and the ENEM databases. The Higher Education Census provides a comprehensive overview of all higher education institutions in the country, with information about their graduation programs and technical-administrative staff and instructors, as well as individual demographic information on each student matriculated in higher education institutions. The ENEM database contains detailed information on test-takers' scores, along with demo- 
graphic characteristics and questionnaires. We have gained restricted data access to students' identification numbers available in both datasets, which allows us to link them.

We make the following sample restrictions in the Census. First, we limit the analysis to the 2010-2014 Census because reliable individual information started to be reported in 2010 and the most recent available year is $2014 .{ }^{19}$ Second, we exclude private and municipal public institutions because they cannot join SISU. Only public and tuition-free institutions are allowed to participate in the platform. Third, we drop observations from online education programs. Fourth, we restrict our sample to first-year students. Our analysis focuses on the short-run, but first-order, effects of SISU on first-year students because they are still too young to graduate by the last year of our data. After these restrictions, our final sample consists of five cohorts of first-year students - with 2,167,313 individuals - admitted between 2010 and 2014 to federal and state public institutions. We refer to this sample as the Census baseline sample.

We link Census data in a given year with ENEM data in the previous year because these test scores can be potentially used for college admission. Thus, the ENEM data of interest range from 2009 to 2013. Our linking variable is the Brazilian Taxpayer Registry, a number that is uniquely assigned to individuals in the country and used for tax collection purposes and social security claims. The advantage of integrating both datasets is twofold. First, we can identify ENEM test score of students enrolled in higher education institutions. Second, while Census data contain students' place of birth, ENEM data provide information on place of residence at the time the exam is taken. Both locations are considered when measuring students' mobility. We are able to match about 71 percent of the Census baseline sample to the ENEM datasets. ${ }^{20,21}$ We refer this sample as the Census-ENEM matched sample.

Therefore, the Census-ENEM matched sample contains information on all first-year stu-

\footnotetext{
${ }^{19}$ Individual information started to be collected in 2009. Prior to that year, information is only available at more aggregate levels. However, the Brazilian Taxpayer Registry, which is the identification number we use to link the ENEM and Census datasets, are only reported from 2010 onward. Discussions with the INEP staff indicate that the inclusion of the Taxpayer Registry is essential to building a reliable link between both Census and ENEM datasets.

${ }^{20}$ More precisely, 1,539,008 out of 2,167,313 students. Matching rates increase over time due to the growing importance of the ENEM exam and are shown in Appendix III. Unmatched individuals correspond to individuals who did not take the ENEM exam, but enrolled in higher education institutions using Vestibular scores only.

${ }^{21}$ Our matching procedures indicate that we are able to recover test score information of at least one student in 35,420 from 37,462 (95 percent) program-year combinations of our sample. This allows us to infer the average ENEM scores for programs that do not require ENEM scores for admissions and reflects the exam's growing importance to students.
} 
dents in federal and state public institutions registered in on-campus programs, along with information about the program itself (e.g. degree, institution, geographical location, whether and when it adopted SISU, etc.) and several demographic characteristics of students (e.g. tests scores, place of residence before college admission, etc.).

The three outcomes of interest are generated in the following way. ENEM test scores are standardized to have a zero mean and a standard deviation of one across all test takers in each year. Migration dummies indicate whether the place of residence (or the place of birth) is different from the place where the program is located. ${ }^{22}$ We use geographical location measured at the municipality and state levels to capture inter- and intra-state migration patterns. Enrollment outcomes are measured among all ever-registered students in the Census and indicate whether students have had their registration canceled or have requested a leave of absence by the end of their first year. We refer to them as inactive students. Given that canceled registrations likely indicate that the seat was subsequently occupied by another student, we also consider both categories separately. Further details about how data and variables are constructed can be found in Appendix III.

Our research design exploits the gradual transition from decentralization to centralization made possible by SISU. Our third data source — provided by the Ministry of Education — consists of information on when (and if) programs and institutions joined SISU. We add this information to our samples.

Table 1 reports annual descriptive statistics for the final analysis sample from 2010 to 2014. We observe two noteworthy patterns. First, fewer students are admitted through Vestibular exams over time (the fraction decreases from 77 to 39 percent), while more students are admitted through ENEM exams (the proportion goes from 22 to 51 percent). This pattern reflects the rapid expansion of the system over time. Second, we notice a rapid increase in the number of first-year students admitted under affirmative action policies. The share of first-year students benefited from quota systems grows from 12 to 28 percent. Affirmative action policies have grown in importance over time, and while they are likely unrelated to SISU adoption, we will consider quota controls in our empirical strategy. ${ }^{23}$

\footnotetext{
${ }^{22}$ Information regarding birthplace is available in the Census datasets for nearly 70 percent of first-year students (that is, $1,517,614$ out of $2,167,313$ individuals).

${ }^{23}$ Prior to 2012, affirmative action policies relied on very few and independent initiatives of institutions and local governments. They started in 2002, when two public universities from Rio de Janeiro (UERJ and UENF) and one from Bahia (UNEB) introduced a system of quotas to admit students (Assunção and Ferman, 2011). That was followed by one university in Brasília (UnB) in 2004 and one university in São
} 


\section{Empirical Model}

\subsection{Empirical Strategy}

To investigate how the introduction of a centralized admission system affects scores, migration, and enrollment of first-year students, we estimate the following equation:

$$
Y_{i p t}=c+\beta S I S U_{p t}+\delta X_{i t}+\gamma X_{p t}+\alpha_{p}+\alpha_{t}+\alpha_{s} * t+\varepsilon_{i p t}
$$

in which $Y_{i p t}$ is the outcome of interest for student $i$ enrolled in program $p$ and year $t$, and $S I S U_{p t}$ indicates whether program $p$ (partially or fully) adopted the SISU system in year $t$. The regression also includes year and program fixed effects, $\alpha_{t}$ and $\alpha_{p}$. Year fixed effects control for common shocks that affect all students each year, whereas program fixed effects control for time-invariant characteristics of programs that might be correlated with the outcomes of interest and the decision to adopt a centralized admission. To capture unobserved state characteristics that evolve over time, we add state linear time trends, $\alpha_{s}{ }^{*} t$. Standard errors are clustered at the institution level. ${ }^{24}$

We introduce student- and program-level control variables in the baseline regression, represented by the vectors $X_{i t}$ and $X_{p t}$, respectively. Individual controls include gender, age, race, a dummy for disability, and indicator variables for affirmative action admission through quota policies and for whether the student receives social support. ${ }^{25}$ Program-level characteristics barely vary over the study period. To ensure that our estimates are not driven by supply side effects, we include the annual number of seats available in each program. ${ }^{26}$

Paulo (UNICAMP) in 2005 (Francis and Tannuri-Pianto, 2012; Estevan et al., 2016). In 2012, the enactment of a federal quota law mandated that half of the seats in federal institutions to be reserved for affirmative action candidates until 2016. The implementation of affirmative action policies remains optional for other institutions, including state public institutions. Ever since, many public institutions have started reserving some of their seats for students from public schools and low-income families, including those who are African or indigenous descent.

${ }^{24}$ Clustering standard errors at the institution level, rather than program level, is a more conservative specification. Our findings remain robust to specifications that replace program fixed effects by institution fixed effects and consider the transition from a decentralized to a centralized admission by institutions. We also consider treatment intensity by interacting $S I S U_{p t}$ with the fraction of students admitted using ENEM scores. These results are available upon request.

${ }^{25}$ Social support comprises food, housing, and material support, among others.

${ }^{26}$ The expansion of the number of seats available in federal public institutions started in 2007 with REUNI (Reestruturação e Expansão das Universidades Federais). Specifically designed for federal universities, this initiative aimed at boosting college access and retention by increasing the number of undergraduate programs and spots, building new campuses in remote areas, hiring more lecturers, and renovating existing buildings. In 2008, the second year of the program, nearly 98 percent of federal universities agreed to join this new 
We consider the effects on admission scores as the primary consequence of centralization. In recognition that any measured impact on migration and enrollment status can be mediated by this margin of selection, we will further consider including ENEM scores as regression controls when looking at these two outcomes.

\subsection{The Adoption of SISU}

Institutions were granted autonomy and flexibility on their decision to adopt the clearinghouse. Approval hinged on majority agreement of voting members of the institution's council (generally composed of the dean and department chairs). In many cases, the decision was heated and tight. A common argument in favor of SISU was the fairness and efficiency that the centralized mechanism provides to applicants, whereas a prominent argument against was the loss of autonomy in recruiting students. The Ministry of Education, in turn, offered the same incentives and compensation for institutions to join the clearinghouse. While the adoption of SISU occurred at the institution level, each programs could still decide how many seats would be offered by the system.

Our empirical strategy relies on the assumption that the timing of the adoption of a new centralized clearinghouse is exogenous with respect to the outcomes of interest, conditional on programs and students' characteristics and program and year fixed effects. We note that our baseline regression performs a within-program analysis by comparing each program to itself before and after centralization. Thus, any concern related to fixed program (and institution) characteristics influencing the decision to move to a centralized admission is fully addressed by this empirical strategy.

Table 2 shows that adopting a centralized mechanism is not associated with the majority of institutions' characteristics at conventional levels of significance. The table compares the characteristics of institutions that ever adopt SISU with non-adopters in our analysis sample using Census data from 2009, the year before the creation of SISU. We notice, however, a few important differences. As expected, federal institutions are more likely to join the SISU system. Unsurprisingly, they are also larger (with a higher number of students and instructors) and more likely to have bachelor's degree programs, which are features strongly correlated with federal public institutions. These differences are accounted for by the

initiative. Given that this program was largely adopted prior to the establishment of SISU, we expect this expansion to be uncorrelated with SISU adoption. 
inclusion of program fixed effects. In addition, previous findings in Szerman (2015) suggest that our results are not sensitive to considering federal and state institutions separately. We also note that institutions located in the Brazilian southeast region, which is one of the five administrative regions in Brazil, are less likely to adopt the SISU system. This region hosts the largest cities and labor markets in the country. The inclusion of program fixed effect also absorbs region and state fixed effects. Nonetheless, since evolving state conditions could confound the effects of SISU adoption, we include state-specific trends.

The existence of some unobservable time-varying factors that affect the adoption of the clearinghouse would be more concerning. Indeed, in the school context, Ekmekci and Yenmez (2014) argue that every school prefers to evade a centralized clearinghouse if all other schools have joined it, under a setting in which leftover schools are able to attract applications from all students. In our college setting, in Brazil, decentralized admissions generally consist of taking specific examinations for each institution. Thus, it is unlikely that leftover institutions would be able to capture these other applications. In addition, increased adoption of SISU over time corroborates that this possibility is not at play. Nonetheless, we conduct an eventstudy analysis to investigate time-varying determinants of adoption by including institution and year fixed effects, as well as dummies indicating the time relative to SISU adoption (timing $e$ is generated as current year minus year of SISU adoption, and event dummies indicate $e=\leq-5,-4,-3,-2,-1,1,2,3$ and 4 , relative to $e=0)$. We rely on aggregate information of institutions from the Higher Education Census since 2000 and examine the few outcomes available in these data. ${ }^{27}$ Results are displayed in Table 3. We do not find effects on institutions' characteristics before and after SISU, further reinforcing the interpretation of a nearly random adoption of the clearinghouse across public institutions in Brazil. ${ }^{28}$

\footnotetext{
${ }^{27}$ The dependent variables are the total number of first-year students, total number of employees, share of employees with college degree or higher, total number of professors, share of professors with a PhD degree, and total amount of own revenues, transfers, and other revenues. These variables are consistently found between 2000 and 2014 and are mostly reported at the institution level. In 2009, information on revenues or transfers were omitted. Our sample consists of institutions that ever adopted SISU between 2010 and 2014.

${ }^{28} \mathrm{It}$ is important to note we do not find evidence that institutions adopting SISU were compensated by increased transfers from the Ministry of Education or hurt by lost revenues from the Vestibular fees. However, we interpret this finding with caution because of possible measurement error in these variables (which are self-reported in the Census).
} 


\subsection{Indirect Effects}

While changes in admission standards are the expected first order effects of centralization, tests scores could also go hand in hand with other student characteristics. Therefore, before turning to our main results, we examine whether the introduction of SISU changes the composition of students in several observable dimensions. Table 4 reports the withinprogram estimates, controlling for state trends, in which each of the students' and programs' observable characteristics are dependent variables.

Overall, we find weak evidence of student selection based on observable characteristics, with the exception of age and gender. The positive effect on age is expected because retaking the ENEM exam, which takes place only once a year, is possible. As for gender, evidence in the literature suggests that women are more risk-averse than men and perform relatively worse under competition (Gneezy et al., 2003; Niederle and Vesterlund, 2007). The negative coefficient indicates that girls are more responsive to centralization. Nonetheless, both effects are economically small. ${ }^{29}$ We also examine changes in program size, measured by the number of seats offered by each program, $X_{p t}$. We find weak evidence of supply side effects, although the small coefficient is statistically significant. Nonetheless, we include all these variables as controls, but do not expect results to change with their inclusion.

Table 4 suggests that there were no systematic changes in students' and programs' observable characteristics after the introduction of SISU. Thus, any effect on student sorting, migration, and enrollment can be attributed to centralization rather than changes in student composition or program characteristics along the above dimensions.

\section{$5 \quad$ Results}

\subsection{Effects on ENEM Scores}

In Brazil, public institutions are generally perceived as having high quality programs. Therefore, we expect them to attract better students after adopting SISU. Table 5 documents

\footnotetext{
${ }^{29}$ To reinforce that our results are not driven by student selection, we consider an additional set of student characteristics, gathered from the ENEM questionnaire, including parental education, family income, and length of school education. Table 12, Appendix IV, indicates that other observable student characteristics are not affected by the implementation of SISU, except for a smaller fraction of first-year students with low family income and living in non-urban areas. Albeit significant, these coefficients are quantitatively negligible.
} 
the findings on student sorting. Column (1) reports the estimates for the model with no controls and documents a positive relationship between test scores and the adoption of SISU. Adding program and year fixed effects in Column (2) indicates that the within-program comparison is stronger. Columns (3) and (4) include individual and program level controls, respectively. Results barely change, consistent with those characteristics being uncorrelated with SISU adoption, as suggested in the previous section.

State-specific trends are considered in Columns (5) and (6) and reduce the point estimate by less than 10 percent. Column (5) displays the coefficients for a specification with all fixed effects and state trends. Column (6) is our preferred specification with all controls. We find that the introduction of a centralized assignment leads to an increase of 0.302 standard deviations of the ENEM score distribution. ${ }^{30}$

Finally, it is important to note that our sample includes all students ever enrolled as first-year students, regardless of their registration situation by the end of the academic year. Column (7) restricts the sample analysis to students that are enrolled by the end of their first year. We find similar effects, indicating that dropouts are in great part high achievers moving to preferred programs.

These findings are related to empirical literature focused on understanding how education policies affect sorting, rather than their impacts on achievement (Urquiola, 2005). The entry of private schools in the market (Epple and Romano, 1998), greater school choices (Urquiola and Verhoogen, 2009), affirmative action bans (Arcidiacono et al., 2014), information on school quality (Hastings and Weinstein, 2008) and changes in admission systems (Bordon and $\mathrm{Fu}, 2015)$ are some examples of policies that lead to more efficient sorting of students.

\subsection{Effects on Migration}

We next turn to investigate the effects on migration. Table 6, Panel A, presents the results for interstate migration, using the ENEM-Census matched sample. In this case, migration

\footnotetext{
${ }^{30}$ The overall effect, however, does not inform which areas of knowledge experienced a higher increase in scores. Institutions are granted flexibility to place different weights on areas of knowledge to calculate the composite score for each program. This discretion allows programs to attract students with a better fit. For example, medical programs commonly set a greater weight on Natural Science and engineering programs might value Math more heavily. When we run Equation (1) separately for each area of knowledge, we find that essay scores have a larger increase in scores; the estimated coefficient is 0.359 SD. This effect is noticeable when compared to the increase experienced by other areas, which ranges from 0.184 to 0.203 SD, and suggests that substantial weight is placed on the only area without multiple choice questions. These findings are available upon request.
} 
is related to the place of residence when ENEM is taken. The within-program estimate in Column (2) indicates a higher likelihood of migration after introducing a centralized admission by 5.8 percentage points (p.p.). However, the effect is halved once individual level controls, particularly ENEM scores, are added. Column (3) reveals that individuals with higher scores are more likely to migrate. Once we control for scores, the effect of SISU on migration is reduced to 2.4 p.p. and remain stable after the inclusion of program controls and state trends, as shown in Columns (4) and (5). In Column (6), we restrict the sample to students who remain enrolled by the end of their first year. The lower coefficient among enrolled students (2.1 p.p.) indicates that migration effects are higher for the dropout sample and highlights that migration costs are not negligible for persistence in higher education.

Table 6, Panel B, displays the results for alternative migration measures. Column (1) repeats our preferred specification in Column (5) of Panel A. We start by considering migration defined at the municipality level in Column (2). We find lower, but still positive and significant effects (1.4 p.p.), indicating that mobility across municipalities was common even before SISU. Selective migration before college is also of concern, as students might already have located near the places where they plan to live when they take the ENEM exam. Therefore, we also examine results that rely on birthplace information available in Census data. We note, however, that birthplace information is missing for 70 percent of students in the Census baseline sample. In Columns (3) and (4), we consider results using the matched ENEM-Census sample and controlling for ENEM scores. In Columns (5) and (6), we consider the Census baseline sample without controlling for ENEM test scores.

One striking pattern emerges. Results are nearly identical across Columns (3) and (5) (as well as Columns (4) and (6)). Controlling for ENEM scores is mainly irrelevant for migration related to place of birth. This evidence enhances the argument for the use of place of birth being more exogenous. Overall, results based on place of birth indicate a sizable and statistically significant effect on student mobility, ranging from 2.9 p.p. to 3.1 p.p. for interstate migration and 3.3 p.p. to 3.4 p.p. for cross-municipality migration. The implied travel distance given by Columns (2), (4), and (6) are 26.5, 28.9, and 31.2 kilometers, respectively. ${ }^{31}$ Since migration likelihood only changes by 3 p.p., the distance incurred by students that actually move is as large as 1.000 kilometers (or equivalently, a little less than

\footnotetext{
${ }^{31}$ Results are available upon request. We estimated similar specifications replacing the migration indicator by distance between the centroids of the source and receiving municipality. If those were in the same municipality, distance was considered as zero.
} 
the distance between Rio de Janeiro and Brasília).

Our findings are consistent with Niederle and Roth (2003) and Abdulkadiroğlu et al. (2015). Niederle and Roth (2003) find that the implementation of a centralized clearinghouse in the gastroenterology medical market increased mobility by widening the scope of the market. In the school choice context, Abdulkadiroğlu et al. (2015) show that a centralized assignment system enhances students' willingness to travel, in comparison to a previously uncoordinated mechanism, even though daily commutes are costly to school students. Our findings suggest that college admission is more closely related to the medical market, since tertiary students face fewer restrictions on migration than school students.

Furthermore, our results have relevant policy implications. Recently, many countries have implemented policies to attract college-educated workers (Guellec and Cervantes, 2002; Groen, 2004). One recurrent argument to justify these interventions is that attending college in a specific state might increase the probability of remaining in the same state after graduation (Fitzpatrick and Jones, 2012). However, our findings show that application costs hinder mobility in the college market and that centralized assignment helps to reduce these frictions by mitigating geographical constraints.

\subsection{Effects on Enrollment}

Finally, we look at the enrollment status of ever-registered students by the end of the academic year. On the one hand, improved matches between students and programs could translate into higher persistence rates. On the other hand, admitted students are now also more likely to come from more distant places. Thus, migration and subsistence costs could act as countervailing forces.

Table 7 displays the results. Column (1) considers the likelihood of an ever-registered student being inactive either because her initial registration has been cancelled or because she has requested leave of absence. It shows that inactivity increases by 4.3 p.p. with SISU. In Column (2), we confirm that the coefficient remains robust when we consider the Census baseline sample (and no test score control).

We note, however, that there is an important difference between registration cancellation and leave of absence status. While requesting leave of absence allows students to re-enroll at the program at a later date, a registration cancellation implies the seat is left vacant for 
another student. ${ }^{32}$ We then consider the two enrollment statuses separately in Columns (3) and (4). The results indicate that the previously found effect on inactivity is mainly driven by canceled registrations. Since the test score effects of SISU on inactive students are even higher than on enrolled students (Table 5, Columns (6) and (7)), we speculate that students who have had their registration canceled have opted for another preferred program. ${ }^{33}$ In Column (5), we drop canceled registrations from the sample, and the results on leave of absence remain very small, in spite of being statistically significant. Nonetheless, in Column (6), we consider an alternative seat vacancy measure, generated as 1 minus the ratio of the number of enrolled students by the end of the year and the total number of seats available in the program. We find no effect on seats left vacant through this alternative measure.

In sum, centralization increases the turnover rate of seats available through the system, as the same seat is occupied by other students beyond its last holder. Moreover, final enrollment rates are not affected by SISU. The last finding is unsurprising in the context of Brazil, given that public institutions are in high demand and are able to recruit candidates from a waitlist until all seats are occupied.

\subsection{Winners and Losers?}

A natural extension to our results is whether and how the impacts of centralization differ across programs according to their different levels of selectivity and fields of study. To do so, we combine the 2009 ENEM microdata with the 2010 Census data to calculate the average ENEM scores of first-year students from programs listed in the 2010 Census. We divide these scores into quartiles to obtain a proxy for programs' selectivity. Thereafter, we estimate Equation (1) by quartile, in which the first quartile represents the smallest and the fourth quartile refers to the largest average ENEM scores. ${ }^{34}$ Table 8 presents the results. We find similar and homogeneous effects in all quartiles, suggesting that centralization tends to yield improvements to all programs, regardless of their selectivity.

Furthermore, we test for heterogeneous effects across fields of study. Following the international classification of fields of education and training (UNESCO Normalized International

\footnotetext{
${ }^{32}$ Re-enrollment after a leave request is subject to internal rules defined by each institution. In general, students can request to be on leave only after completing one semester.

${ }^{33} \mathrm{~A}$ new registration is possible both within SISU (if the student was waitlisted in her first option), or in seats available outside SISU.

${ }^{34}$ We replicate these steps for an alternative combination of the 2013 ENEM microdata with the 2014 Census, as a robustness check. The findings remain similar.
} 
Classification of Education), we categorize all degrees into eight groups: Education; Humanities and Arts; Social Sciences; Business and Law; Science; Engineering, Manufacturing and Construction; Agriculture; Health and Welfare. Table 9 reports the estimates. Consistent with the previous results, we find that SISU adoption leads to similar impacts on test scores, migration, and enrollment status in almost all fields.

Taken together, Tables 8 and 9 suggest that centralization does not favor specific programs. Switching into a centralized admission system would likely create positive impacts for all college degrees and institutions that are able to recruit in a broader market.

\section{Conclusion}

In recent years, the creation of centralized clearinghouses has become a widespread education policy under the argument that they provide broader access to all candidates and produce better outcomes (Hoxby, 2003; Abdulkadiroğlu et al., 2015; Hatfield et al., 2016). In this paper, we provide some of the first empirical evidence on the consequences of centralization in the college market.

To do so, we exploit variation induced by the gradual introduction of a new centralized clearinghouse across higher education institutions between 2010 and 2014 in Brazil, yielding three primary results. First, we find that the adoption of a centralized mechanism largely impacts the quality of incoming students, which is measured by their standardized test scores. This positive effect corresponds to an increase by approximately one-third of a standard deviation, which can be interpreted as a result of better student-institution matches. Second, we find that centralization positively affects students' mobility. The likelihood of attending college in a different state is increased by a sizable amount, guaranteeing fair access beyond geography. Third, we find negligible effects of centralization on final enrollment rates, but positive effects on the turnover rate of seats, indicating a higher search intensity by students. Overall, we find positive effects of centralization in the college market.

The setting of our study indicates that these findings can be extended more broadly to any admission or recruiting effort made at a large geographical scale, such as post-graduate admission or labor market recruitment. Key features in the setting should encompass a unique metric that ranks candidates and the absence of geographical restrictions in the admission process. Our findings also underscore broader questions for further research. 
Given that college education is an important determinant of returns in the labor market, future work will investigate the cumulative and long-run effects of college centralization. 


\section{References}

Abdulkadiroğlu, A., N. Agarwal, and P. A. Pathak (2015). The Welfare Effects of Coordinated Assignment: Evidence from the NYC HS Match. Working Paper 21046, National Bureau of Economic Research.

Abdulkadiroğlu, A., P. A. Pathak, and A. E. Roth (2005). The New York City High School Match. American Economic Review, 364-367.

Abdulkadiroğlu, A. and T. Sönmez (2003). School Choice: A Mechanism Design Approach. The American Economic Review 93(3), 729-747.

Agarwal, N. (2015). An Empirical Model of the Medical Match. American Economic Review $105(7)$, 1939-78.

Arcidiacono, P., E. Aucejo, P. Coate, and V. J. Hotz (2014). Affirmative Action and University Fit: Evidence from Proposition 209. IZA Journal of Labor Economics 3(1), 1.

Arcidiacono, P., E. M. Aucejo, H. Fang, and K. I. Spenner (2011). Does Affirmative Action Lead to Mismatch? A New Test and Evidence. Quantitative Economics 2(3), 303-333.

Arcidiacono, P. and M. Lovenheim (2016). Affirmative Action and the Quality-Fit Trade-Off. Journal of Economic Literature 54(1), 3-51.

Assunção, J. and B. Ferman (2011). Does Affirmative Action Enhance or Undercut Investment Incentives? Evidence from Quotas in Brazilian Public Universities. Manuscript, Massachusetts Institute of Technology Department of Economics.

Bettinger, E. P., B. T. Long, P. Oreopoulos, and L. Sanbonmatsu (2012). The Role of Application Assistance and Information in College Decisions: Results from the H\&R Block Fafsa Experiment. The Quarterly Journal of Economics 127(3), 1205-1242.

Black, S. E., K. E. Cortes, and J. A. Lincove (2015). Academic Undermatching of HighAchieving Minority Students: Evidence from Race-Neutral and Holistic Admissions Policies. The American Economic Review 105(5), 604-610.

Bordon, P. and C. Fu (2015). College-Major Choice to College-Then-Major Choice. The Review of Economic Studies 82(4), 1247-1288. 
Camargo, B., R. Camelo, S. Firpo, and V. P. Ponczek (2014). Information, Market Incentives, and Student Performance. IZA Discussion Paper 7941.

Carrell, S. E. and B. Sacerdote (2013). Why Do College Going Interventions Work? Working Paper 19031, National Bureau of Economic Research.

Chade, H., G. Lewis, and L. Smith (2014). Student Portfolios and the College Admissions Problem. The Review of Economic Studies 81(3), 971-1002.

Che, Y.-K. and Y. Koh (2016). Decentralized College Admissions. Journal of Political Economy 124(5), 1295-1338.

Cohodes, S. R. and J. S. Goodman (2014). Merit Aid, College Quality, and College Completion: Massachusetts' Adams Scholarship as an In-Kind Subsidy. American Economic Journal: Applied Economics 6(4), 251-285.

Dillon, E. and J. Smith (2016). Determinants of the Match between Student Ability and College Quality. Journal of Labor Economics, forthcoming.

Dinkelman, T. and C. Martínez (2014). Investing in Schooling in Chile: The Role of Information about Financial Aid for Higher Education. Review of Economics and Statistics 96(2), $244-257$.

Ekmekci, M. and M. B. Yenmez (2014). Integrating Schools for Centralized Admissions. Available at SSRN 2474700 .

Epple, D. and R. E. Romano (1998). Competition Between Private and Public Schools, Vouchers, and Peer-Group Effects. American Economic Review, 33-62.

Estevan, F., T. Gall, and L.-P. Morin (2016). Redistribution Without Distortion: Evidence from an Affirmative Action Program at a Large Brazilian University. Technical report, University of São Paulo (FEA-USP).

Fitzpatrick, M. D. and D. Jones (2012). Higher Education, Merit-Based Scholarships and Post-Baccalaureate Migration. Working Paper 18530, National Bureau of Economic Research. 
Francis, A. M. and M. Tannuri-Pianto (2012). Using Brazil's Racial Continuum to Examine the Short-Term Effects of Affirmative Action in Higher Education. Journal of Human Resources 47(3), 754-784.

Fu, C. (2014). Equilibrium Tuition, Applications, Admissions, and Enrollment in the College Market. Journal of Political Economy 122(2), 225-281.

Gale, D. and L. S. Shapley (1962). College Admissions and the Stability of Marriage. American Mathematical Monthly, 9-15.

Gneezy, U., M. Niederle, and A. Rustichini (2003). Performance in Competitive Environments: Gender Differences. The Quarterly Journal of Economics 118(3), 1049-1074.

Goodman, S. (2016). Learning from the Test: Raising Selective College Enrollment by Providing Information. The Review of Economics and Statistics 98(4), 671-684.

Groen, J. A. (2004). The Effect of College Location on Migration of College-Educated Labor. Journal of Econometrics 121(1), 125-142.

Guellec, D. and M. Cervantes (2002). International Mobility of Highly Skilled Workers: From Statistical Analysis to Policy Formulation. In International Mobility of the Highly Skilled, Chapter 3, pp. 71-98. OECD Publishing.

Hafalir, I. E., R. Hakimov, D. Kübler, and M. Kurino (2014). College Admissions with Entrance Exams: Centralized versus Decentralized. No. SP II 2014-208. WZB Discussion Paper.

Hastings, J. S., C. A. Neilson, and S. D. Zimmerman (2013). Are Some Degrees Worth More than Others? Evidence from college admission cutoffs in Chile. Working Paper 19241, National Bureau of Economic Research.

Hastings, J. S. and J. M. Weinstein (2008). Information, School Choice, and Academic Achievement: Evidence from Two Experiments. The Quarterly Journal of Economics 123(4), 1373-1414.

Hatfield, J. W., F. Kojima, and Y. Narita (2016). Improving Schools through School Choice: A Market Design Approach. Journal of Economic Theory. 
Hoper Educação (2014). Análise Setorial do Ensino Superior Privado - Brasil 2014. Hoper Estudos de Mercado.

Hoxby, C. and C. Avery (2014). The Missing "One-Offs": The Hidden Supply of HighAchieving, Low-Income Students. Brookings Papers on Economic Activity.

Hoxby, C. and S. Turner (2013). Expanding College Opportunities for High-Achieving, Low Income Students. Stanford Institute for Economic Policy Research Discussion Paper (12014).

Hoxby, C. and S. Turner (2015). What High-Achieving Low-Income Students Know about College. American Economic Review 105(5), 514-17.

Hoxby, C. M. (2003). School Choice and School Productivity. Could School Choice Be a Tide that Lifts all Boats? In The Economics of School Choice, pp. 287-342. University of Chicago Press.

Kirkeboen, L., E. Leuven, and M. Mogstad (2016). Field of study, earnings, and self-selection. The Quarterly Journal of Economics.

Narita, Y. (2016). Match or Mismatch: Learning and Inertia in School Choice. Working Paper.

Niederle, M. and A. E. Roth (2003). Unraveling Reduces Mobility in a Labor Market: Gastroenterology With and Without a Centralized Match. Journal of Political Economy $111(6), 1342-1352$.

Niederle, M. and L. Vesterlund (2007). Do Women Shy Away From Competition? Do Men Compete Too Much? The Quarterly Journal of Economics 122(3).

Oreopoulos, P. and R. Dunn (2013). Information and College Access: Evidence from a Randomized Field Experiment. The Scandinavian Journal of Economics 115(1), 3-26.

Pallais, A. (2015). Small Differences that Matter: Mistakes in Applying to College. Journal of Labor Economics 33, 493-520.

Roth, A. E. and X. Xing (1997). Turnaround time and bottlenecks in market clearing: Decentralized matching in the market for clinical psychologists. Journal of Political Economy 105(2), 284-329. 
Sander, R. H. and S. Taylor (2012). Mismatch: How Affirmative Action Hurts Students It's Intended to Help, and Why Universities Won't Admit It. Basic Books.

Szerman, C. (2015). The Effects of a Centralized College Admission Mechanism on Migration and College Enrollment: Evidence from Brazil. http://bibliotecadigital.fgv.br/dspace/handle/10438/13875.

Urquiola, M. (2005). Does School Choice Lead to Sorting? Evidence from Tiebout Variation. The American Economic Review 95(4), 1310-1326.

Urquiola, M. and E. Verhoogen (2009). Class-Size Caps, Sorting, and the RegressionDiscontinuity Design. The American Economic Review 99(1), 179-215. 
Figure 1: Evolution of ENEM

Table 1: Descriptive Statistics, Census-ENEM Matched Sample

\begin{tabular}{|c|c|c|c|c|c|}
\hline Variables & 2010 & 2011 & 2012 & 2013 & 2014 \\
\hline standardized ENEM scores & $\begin{array}{c}1.14 \\
(0.97)\end{array}$ & $\begin{array}{l}1.14 \\
(0.92)\end{array}$ & $\begin{array}{c}1.15 \\
(0.96)\end{array}$ & $\begin{array}{c}1.16 \\
(0.99)\end{array}$ & $\begin{array}{c}1.27 \\
(1.04)\end{array}$ \\
\hline$\%$ migration (municipality) & $\begin{array}{c}0.53 \\
(0.50)\end{array}$ & $\begin{array}{c}0.50 \\
(0.50)\end{array}$ & $\begin{array}{c}0.50 \\
(0.50)\end{array}$ & $\begin{array}{c}0.50 \\
(0.50)\end{array}$ & $\begin{array}{c}0.49 \\
(0.50)\end{array}$ \\
\hline$\%$ migration (state) & $\begin{array}{c}0.11 \\
(0.31)\end{array}$ & $\begin{array}{c}0.09 \\
(0.29)\end{array}$ & $\begin{array}{c}0.09 \\
(0.29)\end{array}$ & $\begin{array}{c}0.10 \\
(0.29)\end{array}$ & $\begin{array}{c}0.10 \\
(0.30)\end{array}$ \\
\hline$\%$ inactive & $\begin{array}{c}0.12 \\
(0.32)\end{array}$ & $\begin{array}{c}0.11 \\
(0.31)\end{array}$ & $\begin{array}{c}0.13 \\
(0.34)\end{array}$ & $\begin{array}{c}0.13 \\
(0.33)\end{array}$ & $\begin{array}{c}0.14 \\
(0.34)\end{array}$ \\
\hline$\%$ SISU* & $\begin{array}{c}0.23 \\
(0.42)\end{array}$ & $\begin{array}{c}0.37 \\
(0.48)\end{array}$ & $\begin{array}{c}0.44 \\
(0.50)\end{array}$ & $\begin{array}{c}0.51 \\
(0.50)\end{array}$ & $\begin{array}{c}0.62 \\
(0.48)\end{array}$ \\
\hline$\%$ Vestibular & $\begin{array}{c}0.77 \\
(0.42)\end{array}$ & $\begin{array}{c}0.67 \\
(0.47)\end{array}$ & $\begin{array}{c}0.55 \\
(0.50)\end{array}$ & $\begin{array}{c}0.47 \\
(0.50)\end{array}$ & $\begin{array}{c}0.39 \\
(0.49)\end{array}$ \\
\hline$\%$ ENEM & $\begin{array}{c}0.22 \\
(0.47)\end{array}$ & $\begin{array}{c}0.28 \\
(0.48)\end{array}$ & $\begin{array}{c}0.36 \\
(0.50)\end{array}$ & $\begin{array}{c}0.48 \\
(0.50)\end{array}$ & $\begin{array}{c}0.51 \\
(0.50)\end{array}$ \\
\hline$\%$ female & $\begin{array}{c}0.54 \\
(0.50)\end{array}$ & $\begin{array}{c}0.52 \\
(0.50)\end{array}$ & $\begin{array}{c}0.53 \\
(0.50)\end{array}$ & $\begin{array}{c}0.52 \\
(0.50)\end{array}$ & $\begin{array}{c}0.51 \\
(0.50)\end{array}$ \\
\hline age & $\begin{array}{l}21.05 \\
(5.05)\end{array}$ & $\begin{array}{l}21.52 \\
(5.61)\end{array}$ & $\begin{array}{l}21.63 \\
(5.78)\end{array}$ & $\begin{array}{l}21.74 \\
(6.00)\end{array}$ & $\begin{array}{l}22.12 \\
(6.41)\end{array}$ \\
\hline$\%$ white & $\begin{array}{c}0.20 \\
(0.40)\end{array}$ & $\begin{array}{c}0.22 \\
(0.41)\end{array}$ & $\begin{array}{c}0.23 \\
(0.42)\end{array}$ & $\begin{array}{c}0.23 \\
(0.42)\end{array}$ & $\begin{array}{c}0.32 \\
(0.47)\end{array}$ \\
\hline$\%$ disabled & $\begin{array}{c}0.00 \\
(0.06)\end{array}$ & $\begin{array}{c}0.00 \\
(0.06)\end{array}$ & $\begin{array}{c}0.00 \\
(0.07)\end{array}$ & $\begin{array}{c}0.01 \\
(0.07)\end{array}$ & $\begin{array}{c}0.01 \\
(0.09)\end{array}$ \\
\hline$\%$ under social support & $\begin{array}{c}0.14 \\
(0.34)\end{array}$ & $\begin{array}{c}0.12 \\
(0.33)\end{array}$ & $\begin{array}{c}0.13 \\
(0.34)\end{array}$ & $\begin{array}{c}0.18 \\
(0.38)\end{array}$ & $\begin{array}{c}0.14 \\
(0.35)\end{array}$ \\
\hline$\%$ admitted through quotas & $\begin{array}{c}0.12 \\
(0.33)\end{array}$ & $\begin{array}{c}0.12 \\
(0.33)\end{array}$ & $\begin{array}{l}0.15 \\
(0.35)\end{array}$ & $\begin{array}{c}0.20 \\
(0.40)\end{array}$ & $\begin{array}{c}0.28 \\
(0.45)\end{array}$ \\
\hline number of seats & $\begin{array}{c}55.74 \\
(46.31)\end{array}$ & $\begin{array}{c}58.94 \\
(50.95)\end{array}$ & $\begin{array}{c}57.65 \\
(49.32)\end{array}$ & $\begin{array}{c}57.78 \\
(49.37)\end{array}$ & $\begin{array}{c}55.95 \\
(48.68)\end{array}$ \\
\hline Observations & 237.737 & 293.711 & 319.868 & 334.712 & 352.980 \\
\hline
\end{tabular}

Note: This table reports yearly descriptive statistics for first-year students enrolled in federal and state public institutions over the 2010-2014 period. The sample includes all students who took the ENEM exam in the previous year. Table displays means and standard deviations in parenthesis. Sources: 2010-2014 Higher Education Censuses and ENEM microdata.

* - Calculated using the Census baseline sample.

Note: Graph shows, on the left axis, how the number of ENEM applicants rapidly evolved, since its first edition. On the right axis, graph shows the ratio of total number of applicants divided by the number of high school graduates. Information on applicants is obtained from ENEM microdata. Information on high school graduates is obtained from the annual School Census. The first edition, in 1998, received 157,221 registrations (approximately 0.1 percent of the Brazilian population), while the last edition received 8,721,946 registrations (roughly 4.3 percent of the Brazilian population), in 2014. 
Table 2: 2009 Characteristics of Treated and Untreated Institutions

\begin{tabular}{lccc}
\hline \hline & Untreated & Treated & p-Value \\
\hline Observations & 69 & 109 & - \\
\hline A. Students' Characteristics & & & \\
\hline ENADE Scores & 0.416 & 0.584 & 0.3344 \\
Inactive & 0.064 & 0.079 & 0.2227 \\
Female & 0.516 & 0.512 & 0.8579 \\
White & 0.229 & 0.212 & 0.6650 \\
Disabled & 0.009 & 0.006 & 0.6182 \\
Admitted through ENEM & 0.044 & 0.050 & 0.8471 \\
Admitted through Vestibular & 0.968 & 0.948 & 0.2749 \\
Migration (State) & 0.146 & 0.170 & 0.3136 \\
Migration (Municipality) & 0.530 & 0.525 & 0.9013 \\
Receive Social Support & 0.040 & 0.059 & 0.4517 \\
Benefited from Quota System & 0.099 & 0.068 & 0.2287 \\
Age & 24.691 & 23.820 & 0.0565 \\
\hline B. Institutions' Characteristics & & & \\
\hline University Institutions & & & \\
Federal Institutions & 0.373 & 0.615 & 0.0017 \\
Bachelor's Degree Programs & 0.060 & 0.826 & 0.0000 \\
Located in State Capital Cities & 0.287 & 0.392 & 0.0225 \\
Located in Central-West Region & 0.281 & 0.301 & 0.7237 \\
Located in North Region & 0.031 & 0.088 & 0.1285 \\
Located in Northeast Region & 0.061 & 0.123 & 0.1732 \\
Located in Southeast Region & 0.164 & 0.277 & 0.0799 \\
Located in South Region & 0.569 & 0.349 & 0.0036 \\
Number of Employees & 0.176 & 0.163 & 0.8198 \\
Number of Students & 753.971 & 917.716 & 0.5245 \\
Number of Programs & 1600.403 & 2570.486 & 0.0106 \\
Number of Teachers & 69.725 & 64.661 & 0.8445 \\
Institutions Have a Lab & 546.609 & 785.771 & 0.0810 \\
\hline \hline & 0.780 & 0.778 & 0.9514 \\
\hline
\end{tabular}

This table reports comparison of 2009 students' and institutions' characteristics of treated and untreated institutions. Treated institutions are those that adopted the centralized clearinghouse at some point between 2010 and 2014. The p-value comes from the $t$-test of equality across both groups. Students' characteristics include standardized ENADE scores of first-year students, the share of inactive, female, white, and disabled students, the fraction of students admitted through ENEM and Vestibular exams, the fraction of students that currently study in a location different from birthplace, the share of students that receive any type of social support, the fraction of students that benefit from quota system, and the average student age. Inactive students are those whose enrollment status is on leave or cancellation. Students' birthplace information is not available in the 2009 Census. The migration indicator corresponds to whether the birthplace is different from the place where the program is located for a sample of second-year students in the 2010 Census. Sources: 2009-2010 Higher Education Censuses and ENADE microdata. 
Table 3: Time-Varying Institution-Level Characteristics and SISU Adoption

\begin{tabular}{|c|c|c|c|c|c|c|c|c|}
\hline & $\begin{array}{c}(1) \\
\text { first-year } \\
\text { students }\end{array}$ & $\begin{array}{c}(2) \\
\text { number of } \\
\text { employees }\end{array}$ & $\begin{array}{c}(3) \\
\text { share with } \\
\text { college }\end{array}$ & $\begin{array}{c}(4) \\
\text { number of } \\
\text { professors }\end{array}$ & $\begin{array}{c}(5) \\
\text { share } \\
\text { with PhD }\end{array}$ & $\begin{array}{c}(6) \\
\text { own } \\
\text { revenues }\end{array}$ & $\begin{array}{c}(7) \\
\text { transfers }\end{array}$ & $\begin{array}{c}(8) \\
\text { other } \\
\text { revenues }\end{array}$ \\
\hline $\mathrm{d}(\mathrm{e}=+4)$ & $\begin{array}{l}-223.526 \\
(533.432)\end{array}$ & $\begin{array}{l}-228.811 \\
(183.301)\end{array}$ & $\begin{array}{c}0.082 \\
(0.055)\end{array}$ & $\begin{array}{l}-40.027 \\
(108.613)\end{array}$ & $\begin{array}{l}-0.024 \\
(0.035)\end{array}$ & $\begin{array}{c}-7.977 \\
(17.171)\end{array}$ & $\begin{array}{c}37.656 \\
(63.679)\end{array}$ & $\begin{array}{c}12.917 \\
(11.783)\end{array}$ \\
\hline $\mathrm{d}(\mathrm{e}=+3)$ & $\begin{array}{l}-125.276 \\
(394.868)\end{array}$ & $\begin{array}{l}-134.690 \\
(146.217)\end{array}$ & $\begin{array}{l}0.068^{*} \\
(0.041)\end{array}$ & $\begin{array}{l}-12.002 \\
(78.488)\end{array}$ & $\begin{array}{l}-0.027 \\
(0.024)\end{array}$ & $\begin{array}{l}-17.345 \\
(20.556)\end{array}$ & $\begin{array}{l}-96.455 \\
(82.058)\end{array}$ & $\begin{array}{c}14.765 \\
(17.338)\end{array}$ \\
\hline $\mathrm{d}(\mathrm{e}=+2)$ & $\begin{array}{l}-105.722 \\
(266.730)\end{array}$ & $\begin{array}{c}-83.325 \\
(105.034)\end{array}$ & $\begin{array}{c}0.026 \\
(0.030)\end{array}$ & $\begin{array}{l}-24.984 \\
(53.080)\end{array}$ & $\begin{array}{l}-0.016 \\
(0.017)\end{array}$ & $\begin{array}{c}11.981 \\
(19.190)\end{array}$ & $\begin{array}{c}-33.818 \\
(50.690)\end{array}$ & $\begin{array}{c}16.526 \\
(10.794)\end{array}$ \\
\hline $\mathrm{d}(\mathrm{e}=+1)$ & $\begin{array}{c}-31.450 \\
(139.051)\end{array}$ & $\begin{array}{l}-56.171 \\
(60.252)\end{array}$ & $\begin{array}{l}-0.002 \\
(0.020)\end{array}$ & $\begin{array}{l}-36.955 \\
(29.541)\end{array}$ & $\begin{array}{l}-0.004 \\
(0.010)\end{array}$ & $\begin{array}{l}-1.780 \\
(7.160)\end{array}$ & $\begin{array}{c}5.980 \\
(29.984)\end{array}$ & $\begin{array}{l}-9.515 \\
(6.118)\end{array}$ \\
\hline $\mathrm{d}(\mathrm{e}=-1)$ & $\begin{array}{c}81.243 \\
(162.543)\end{array}$ & $\begin{array}{c}10.137 \\
(54.708)\end{array}$ & $\begin{array}{c}0.024 \\
(0.019)\end{array}$ & $\begin{array}{c}29.340 \\
(28.585)\end{array}$ & $\begin{array}{c}0.010 \\
(0.008)\end{array}$ & $\begin{array}{c}19.259 \\
(14.904)\end{array}$ & $\begin{array}{l}-44.261 \\
(53.865)\end{array}$ & $\begin{array}{c}-19.492^{* *} \\
(7.785)\end{array}$ \\
\hline $\mathrm{d}(\mathrm{e}=-2)$ & $\begin{array}{c}61.179 \\
(296.903)\end{array}$ & $\begin{array}{c}175.195 \\
(107.526)\end{array}$ & $\begin{array}{c}0.012 \\
(0.027)\end{array}$ & $\begin{array}{c}64.030 \\
(60.442)\end{array}$ & $\begin{array}{c}0.017 \\
(0.015)\end{array}$ & $\begin{array}{c}55.055^{* *} \\
(27.116)\end{array}$ & $\begin{array}{l}-71.261 \\
(90.381)\end{array}$ & $\begin{array}{c}-9.325 \\
(11.426)\end{array}$ \\
\hline$d(e=-3)$ & $\begin{array}{c}113.033 \\
(401.049)\end{array}$ & $\begin{array}{c}26.950 \\
(145.287)\end{array}$ & $\begin{array}{c}0.011 \\
(0.034)\end{array}$ & $\begin{array}{c}73.605 \\
(78.928)\end{array}$ & $\begin{array}{c}0.029 \\
(0.021)\end{array}$ & $\begin{array}{c}41.457 \\
(28.979)\end{array}$ & $\begin{array}{l}-120.179 \\
(113.125)\end{array}$ & $\begin{array}{c}-3.919 \\
(14.692)\end{array}$ \\
\hline $\mathrm{d}(\mathrm{e}=-4)$ & $\begin{array}{c}132.259 \\
(487.317)\end{array}$ & $\begin{array}{c}69.238 \\
(164.584)\end{array}$ & $\begin{array}{c}0.016 \\
(0.039)\end{array}$ & $\begin{array}{c}60.771 \\
(89.058)\end{array}$ & $\begin{array}{c}0.040 \\
(0.026)\end{array}$ & $\begin{array}{c}46.723 \\
(32.154)\end{array}$ & $\begin{array}{c}-68.660 \\
(119.470)\end{array}$ & $\begin{array}{c}-5.689 \\
(14.944)\end{array}$ \\
\hline$d(e \leq-5)$ & $\begin{array}{c}170.936 \\
(545.978)\end{array}$ & $\begin{array}{c}70.156 \\
(168.365)\end{array}$ & $\begin{array}{c}0.023 \\
(0.045)\end{array}$ & $\begin{array}{c}61.652 \\
(104.136)\end{array}$ & $\begin{array}{c}0.038 \\
(0.030)\end{array}$ & $\begin{array}{c}45.840 \\
(30.510)\end{array}$ & $\begin{array}{c}-75.230 \\
(125.913)\end{array}$ & $\begin{array}{c}-2.436 \\
(15.388)\end{array}$ \\
\hline Constant & $\begin{array}{c}1,003.803^{*} \\
(585.613)\end{array}$ & $\begin{array}{c}708.412^{* * *} \\
(173.421)\end{array}$ & $\begin{array}{c}0.351^{* * *} \\
(0.045)\end{array}$ & $\begin{array}{c}499.696^{* * *} \\
(106.421)\end{array}$ & $\begin{array}{c}0.167^{* * * *} \\
(0.028)\end{array}$ & $\begin{array}{l}-43.649 \\
(31.484)\end{array}$ & $\begin{array}{c}128.147 \\
(128.035)\end{array}$ & $\begin{array}{l}-1.401 \\
(14.705)\end{array}$ \\
\hline Observations & 1,319 & 1,319 & 1,319 & 1,319 & 1,319 & 1,210 & 1,210 & 1,210 \\
\hline R-squared & 0.899 & 0.887 & 0.758 & 0.960 & 0.943 & 0.295 & 0.606 & 0.260 \\
\hline Institution FE & $\checkmark$ & $\checkmark$ & $\checkmark$ & $\checkmark$ & $\checkmark$ & $\checkmark$ & $\checkmark$ & $\checkmark$ \\
\hline Year FE & $\checkmark$ & $\checkmark$ & $\checkmark$ & $\checkmark$ & $\checkmark$ & $\checkmark$ & $\checkmark$ & $\checkmark$ \\
\hline Sample & $2000-2014$ & 2000-2014 & $2000-2014$ & $2000-2014$ & 2000-2014 & $\begin{array}{c}2000-2014 \\
\text { except } 2009\end{array}$ & $\begin{array}{c}2000-2014 \\
\text { except } 2009\end{array}$ & $\begin{array}{c}2000-2014, \\
\text { except } 2009\end{array}$ \\
\hline
\end{tabular}

Note: $* * *$ : significant at $1 \%$ level; ${ }^{* *}$ : significant at $5 \%$ level; $*$ : significant at $10 \%$ level. This table reports regression estimates of the annual effects of adopting SISU on different outcomes. The omitted category is the first year of SISU adoption. The dependent variables are the number of first-year students, number of employees, fraction of employees with college degree, number of professors, fraction of professors with $\mathrm{PhD}$ degree, own revenues, transfers and other revenues, respectively. Revenues and transfers are expressed in millions of reais. The sample consists of institutions that ever adopted SISU over the 2010-2014 period and are found in the Higher Education Censuses between 2000 and 2014. Columns (6)-(8) omit 2009, since information on revenues and transfers are not available for that year. In all specifications, institution, and year fixed effects are included. Robust standard errors clustered at institution level are reported in parenthesis. 
Table 4: Effects of SISU on Observable Characteristics of Students and Programs

\begin{tabular}{|c|c|c|c|c|c|c|c|}
\hline & $\begin{array}{c}(1) \\
\text { female }\end{array}$ & $\begin{array}{l}(2) \\
\text { age }\end{array}$ & $\begin{array}{c}(3) \\
\text { white }\end{array}$ & $\begin{array}{c}(4) \\
\text { disabled }\end{array}$ & $\begin{array}{c}(5) \\
\text { admissions } \\
\text { through quota }\end{array}$ & $\begin{array}{c}(6) \\
\text { social } \\
\text { support }\end{array}$ & $\begin{array}{c}(7) \\
\text { number } \\
\text { of seats }\end{array}$ \\
\hline SISU & $\begin{array}{c}-0.022 * * * \\
(0.003)\end{array}$ & $\begin{array}{c}0.534 * * * \\
(0.076)\end{array}$ & $\begin{array}{l}-0.000 \\
(0.023)\end{array}$ & $\begin{array}{c}0.000 \\
(0.001)\end{array}$ & $\begin{array}{c}0.004 \\
(0.028)\end{array}$ & $\begin{array}{c}-0.000 \\
(0.016)\end{array}$ & $\begin{array}{l}1.694^{*} \\
(0.975)\end{array}$ \\
\hline Constant & $\begin{array}{c}0.530^{* * *} \\
(0.002)\end{array}$ & $\begin{array}{c}20.922^{* * *} \\
(0.062)\end{array}$ & $\begin{array}{c}0.287 * * * \\
(0.027)\end{array}$ & $\begin{array}{c}-0.010^{* * *} \\
(0.003)\end{array}$ & $\begin{array}{c}0.126^{* * *} \\
(0.024)\end{array}$ & $\begin{array}{c}0.121^{* * *} \\
(0.013)\end{array}$ & $\begin{array}{c}56.784^{* * *} \\
(0.666)\end{array}$ \\
\hline Observations & $1,539,008$ & $1,539,008$ & $1,539,008$ & $1,539,008$ & $1,539,008$ & $1,539,008$ & 35,420 \\
\hline R-squared & 0.174 & 0.158 & 0.265 & 0.011 & 0.198 & 0.423 & 0.932 \\
\hline Program FE & $\checkmark$ & $\checkmark$ & $\checkmark$ & $\checkmark$ & $\checkmark$ & $\checkmark$ & $\checkmark$ \\
\hline Year FE & $\checkmark$ & $\checkmark$ & $\checkmark$ & $\checkmark$ & $\checkmark$ & $\checkmark$ & $\checkmark$ \\
\hline State Trend & $\checkmark$ & $\checkmark$ & $\checkmark$ & $\checkmark$ & $\checkmark$ & $\checkmark$ & $\checkmark$ \\
\hline
\end{tabular}

Note: ***: significant at $1 \%$ level; **: significant at $5 \%$ level; *: significant at $10 \%$ level. This table presents the effects of moving to SISU on students' and programs' characteristics, after controlling for year and program fixed effects, as well as state trends. The dependent variables are indicator variables for female students, students' age, indicator variables for white and disabled students, students that receive social support, students that benefit from quota system, and total number of seats in each program, respectively. The independent variable SISU is an indicator for whether program $p$ partially or fully adopted the SISU system in the year $t$. Robust standard errors clustered at institution level are reported in parenthesis. Sources: Higher Education Censuses and ENEM microdata. 
Table 5: Effect of SISU on ENEM Scores

\begin{tabular}{|c|c|c|c|c|c|c|c|}
\hline & (1) & $(2)$ & (3) & (4) & (5) & $(6)$ & $(7)$ \\
\hline SISU & $\begin{array}{l}0.157^{*} \\
(0.087)\end{array}$ & $\begin{array}{c}0.324^{* * *} \\
(0.032)\end{array}$ & $\begin{array}{c}0.328^{* * *} \\
(0.032)\end{array}$ & $\begin{array}{c}0.328^{* * *} \\
(0.032)\end{array}$ & $\begin{array}{c}0.300^{* * *} \\
(0.031)\end{array}$ & $\begin{array}{c}0.302^{* * *} \\
(0.030)\end{array}$ & $\begin{array}{c}0.277^{* * * *} \\
(0.029)\end{array}$ \\
\hline Constant & $\begin{array}{c}1.093^{* * *} \\
(0.080)\end{array}$ & $\begin{array}{c}1.029 * * * \\
(0.019)\end{array}$ & $\begin{array}{c}1.226^{* * *} \\
(0.027)\end{array}$ & $\begin{array}{c}1.228^{* * *} \\
(0.032)\end{array}$ & $\begin{array}{c}0.995^{* * *} \\
(0.021)\end{array}$ & $\begin{array}{c}1.193^{* * *} \\
(0.030)\end{array}$ & $\begin{array}{c}1.173^{* * *} \\
(0.029)\end{array}$ \\
\hline $\begin{array}{l}\text { Observations } \\
\mathrm{R}^{2}\end{array}$ & $\begin{array}{c}1,539,008 \\
0.006\end{array}$ & $\begin{array}{c}1,539,008 \\
0.585\end{array}$ & $\begin{array}{c}1,539,008 \\
0.601\end{array}$ & $\begin{array}{c}1,539,008 \\
0.601\end{array}$ & $\begin{array}{c}1,539,008 \\
0.588\end{array}$ & $\begin{array}{c}1,539,008 \\
0.604\end{array}$ & $\begin{array}{c}1,346,489 \\
0.619\end{array}$ \\
\hline Individual Controls & & & $\checkmark$ & $\checkmark$ & & $\checkmark$ & $\checkmark$ \\
\hline Program Controls & & & & $\checkmark$ & & $\checkmark$ & $\checkmark$ \\
\hline Program FE & & $\checkmark$ & $\checkmark$ & $\checkmark$ & $\checkmark$ & $\checkmark$ & $\checkmark$ \\
\hline Year FE & & $\checkmark$ & $\checkmark$ & $\checkmark$ & $\checkmark$ & $\checkmark$ & $\checkmark$ \\
\hline State Trend & & & & & $\checkmark$ & $\checkmark$ & $\checkmark$ \\
\hline Sample & 2010-2014 & 2010-2014 & 2010-2014 & 2010-2014 & 2010-2014 & 2010-2014 & Enrolled \\
\hline
\end{tabular}

Note: $* * *$ : significant at $1 \%$ level; $* *$ : significant at $5 \%$ level; $*$ : significant at $10 \%$ level. This table reports the effects of adopting SISU on standardized ENEM score of first-year students. The sample consists of 1,539,008 students enrolled in federal and state public institutions over the 2010-2014 period. Column (1) presents result for a simple OLS regression. Column (2) displays estimates after controlling for program and year fixed effects, while Column (3) includes a full set of observable student covariates (age, gender, race, disability, indicator for whether the student benefited from quota system and indicator for whether the student receives social support), and program and year fixed effects. Column (4) includes program covariates (number of seats). Column (5) only considers state trends, program and year fixed effects. Column (6) also includes controls, while Column (7) excludes from the sample individuals whose enrollment status is on leave or cancellation. Robust standard errors clustered at institution level are reported in parenthesis. Sources: Higher Education Censuses and ENEM microdata. 
Table 6: Effect of SISU on Migration

\begin{tabular}{|c|c|c|c|c|c|c|}
\hline PANEL A & $\begin{array}{c}\text { (1) } \\
\text { state } \\
\text { ENEM } \\
\end{array}$ & $\begin{array}{c}(2) \\
\text { state } \\
\text { ENEM } \\
\end{array}$ & $\begin{array}{c}\text { (3) } \\
\text { state } \\
\text { ENEM } \\
\end{array}$ & $\begin{array}{c}(4) \\
\text { state } \\
\text { ENEM } \\
\end{array}$ & $\begin{array}{c}(5) \\
\text { state } \\
\text { ENEM } \\
\end{array}$ & $\begin{array}{c}(6) \\
\text { state } \\
\text { ENEM } \\
\end{array}$ \\
\hline SISU & $\begin{array}{c}0.054^{* * *} \\
(0.013)\end{array}$ & $\begin{array}{c}0.058 * * * \\
(0.013)\end{array}$ & $\begin{array}{c}0.024 * * * \\
(0.005)\end{array}$ & $\begin{array}{c}0.023^{* * *} \\
(0.005)\end{array}$ & $\begin{array}{c}0.025 * * * \\
(0.005)\end{array}$ & $\begin{array}{c}0.021^{* * *} * \\
(0.005)\end{array}$ \\
\hline Constant & $\begin{array}{c}0.068^{* * * *} \\
(0.009)\end{array}$ & $\begin{array}{c}0.153^{* * *} \\
(0.016)\end{array}$ & $\begin{array}{c}0.074^{* * *} \\
(0.006)\end{array}$ & $\begin{array}{c}0.066^{* * *} \\
(0.007)\end{array}$ & $\begin{array}{c}0.054^{* * *} \\
(0.007)\end{array}$ & $\begin{array}{c}0.051^{* * *} \\
(0.006)\end{array}$ \\
\hline Observations & $1,539,008$ & $1,539,008$ & $1,539,008$ & $1,539,008$ & $1,539,008$ & $1,346,489$ \\
\hline $\mathrm{R}^{2}$ & 0.008 & 0.014 & 0.172 & 0.172 & 0.173 & 0.172 \\
\hline Individual Controls & & & $\checkmark$ & $\checkmark$ & $\checkmark$ & $\checkmark$ \\
\hline ENEM Score & & & $\checkmark$ & $\checkmark$ & $\checkmark$ & $\checkmark$ \\
\hline Program Controls & & & & $\checkmark$ & $\checkmark$ & $\checkmark$ \\
\hline Program FE & & $\checkmark$ & $\checkmark$ & $\checkmark$ & $\checkmark$ & $\checkmark$ \\
\hline Year FE & & $\checkmark$ & $\checkmark$ & $\checkmark$ & $\checkmark$ & $\checkmark$ \\
\hline State Trend & & & & & $\checkmark$ & $\checkmark$ \\
\hline Sample & $2010-2014$ & $2010-2014$ & $2010-2014$ & $2010-2014$ & $2010-2014$ & Active \\
\hline PANEL B & $\begin{array}{c}(1) \\
\text { state } \\
\text { ENEM } \\
\end{array}$ & $\begin{array}{c}(2) \\
\text { municipality } \\
\text { ENEM }\end{array}$ & $\begin{array}{c}(3) \\
\text { state } \\
\text { birthplace } \\
\end{array}$ & $\begin{array}{c}(4) \\
\text { municipality } \\
\text { birthplace }\end{array}$ & $\begin{array}{c}(5) \\
\text { state } \\
\text { birthplace }\end{array}$ & $\begin{array}{c}(6) \\
\text { municipality } \\
\text { birthplace }\end{array}$ \\
\hline SISU & $\begin{array}{c}0.025 * * * \\
(0.005)\end{array}$ & $\begin{array}{c}0.014^{* *} \\
(0.005)\end{array}$ & $\begin{array}{c}0.029 * * \\
(0.011)\end{array}$ & $\begin{array}{c}0.034^{* *} \\
(0.016)\end{array}$ & $\begin{array}{c}0.031^{* * *} \\
(0.010)\end{array}$ & $\begin{array}{c}0.033 * * * \\
(0.016)\end{array}$ \\
\hline Constant & $\begin{array}{c}0.054^{* * *} * \\
(0.007)\end{array}$ & $\begin{array}{c}0.605^{* * *} \\
(0.011)\end{array}$ & $\begin{array}{c}0.103^{* * *} \\
(0.015)\end{array}$ & $\begin{array}{c}0.550^{* * *} \\
(0.019)\end{array}$ & $\begin{array}{c}0.139 * * * \\
(0.011)\end{array}$ & $\begin{array}{c}0.546^{* * *} \\
(0.014)\end{array}$ \\
\hline Observations & $1,539,008$ & $1,539,008$ & $1,049,651$ & $1,049,651$ & $1,517,614$ & $1,517,614$ \\
\hline $\mathrm{R}^{2}$ & 0.173 & 0.242 & 0.144 & 0.275 & 0.130 & 0.254 \\
\hline Individual Controls & $\checkmark$ & $\checkmark$ & $\checkmark$ & $\checkmark$ & $\checkmark$ & $\checkmark$ \\
\hline ENEM Score & $\checkmark$ & $\checkmark$ & $\checkmark$ & $\checkmark$ & & \\
\hline Program Controls & $\checkmark$ & $\checkmark$ & $\checkmark$ & $\checkmark$ & $\checkmark$ & $\checkmark$ \\
\hline Program FE & $\checkmark$ & $\checkmark$ & $\checkmark$ & $\checkmark$ & $\checkmark$ & $\checkmark$ \\
\hline Year FE & $\checkmark$ & $\checkmark$ & $\checkmark$ & $\checkmark$ & $\checkmark$ & $\checkmark$ \\
\hline State Trend & $\checkmark$ & $\checkmark$ & $\checkmark$ & $\checkmark$ & $\checkmark$ & $\checkmark$ \\
\hline Sample & $2010-2014$ & $2010-2014$ & 2010-2014 & $2010-2014$ & $2010-2014$ & $2010-2014$ \\
\hline
\end{tabular}

Note: ***: significant at $1 \%$ level; ${ }^{* *}$ : significant at $5 \%$ level; ${ }^{*}$ : significant at $10 \%$ level. Panel A reports the effects of adopting SISU on inter-state migration of first-year students. The dependent variable is an indicator for whether the state where the student resided before entering college is different from the state where the student attends college. Column (1) presents result for a simple OLS regression. Columns (2) displays estimates after controlling for program and year fixed effects, while Column (3) includes a full set of observable student covariates (age, gender, race, disability, indicator variables for whether the student is benefited from quota system and receives social support), ENEM scores, and program and year fixed effects. Column (4) includes program covariates (number of seats). Column (5) also considers state trends, while Column (6) excludes from the sample individuals whose enrollment status is on leave or cancellation. Panel B reports the effects of adopting SISU on alternative measures for migration of firstyear students. In Column (1), the dependent variable is the same as in Panel A. Column (2) presents the result for the dependent variable defined as indicator for whether the municipality where the student resided before entering college differs from the municipality where the student attends college. The dependent variable municipality birthplace (state birthplace) is an indicator for whether the municipality (state) of birth is different from the municipality (state) where the student attends college. All columns consider a 3'egression with students' characteristics, program covariates (number of seats), program and year fixed effects, and state trends. Columns (1)-(4) additionally control for ENEM scores. Robust standard errors clustered at institution level are reported in parenthesis. Sources: Higher Education Censuses and ENEM microdata. 


\section{Table 7: Effect of SISU on Enrollment Status}

\begin{tabular}{|c|c|c|c|c|c|c|}
\hline & $\begin{array}{c}(1) \\
\text { inactive }\end{array}$ & $\begin{array}{c}(2) \\
\text { inactive }\end{array}$ & $\begin{array}{c}(3) \\
\text { on leave }\end{array}$ & $\begin{array}{c}(4) \\
\text { cancellation }\end{array}$ & $\begin{array}{c}(5) \\
\text { on leave }\end{array}$ & $\begin{array}{c}(6) \\
\text { vacancy rate }\end{array}$ \\
\hline SISU & $\begin{array}{c}0.043^{* * *} \\
(0.006)\end{array}$ & $\begin{array}{c}0.054 * * * \\
(0.008)\end{array}$ & $\begin{array}{c}0.008 \\
(0.005)\end{array}$ & $\begin{array}{c}0.046^{* * *} \\
(0.007)\end{array}$ & $\begin{array}{l}0.011^{*} \\
(0.006)\end{array}$ & $\begin{array}{c}0.005 \\
(0.018)\end{array}$ \\
\hline Constant & $\begin{array}{c}0.014 \\
(0.016)\end{array}$ & $\begin{array}{c}0.068^{* * *} \\
(0.023)\end{array}$ & $\begin{array}{l}-0.021 \\
(0.016)\end{array}$ & $\begin{array}{c}0.089 * * * \\
(0.016)\end{array}$ & $\begin{array}{l}-0.023 \\
(0.018)\end{array}$ & $\begin{array}{c}-0.119^{* * *} \\
(0.036)\end{array}$ \\
\hline Observations & $1,539,008$ & $2,167,313$ & $2,167,313$ & $2,167,313$ & $1,976,952$ & 37,581 \\
\hline R-squared & 0.116 & 0.100 & 0.071 & 0.100 & 0.077 & 0.481 \\
\hline $\begin{array}{l}\text { Individual Controls } \\
\text { ENEM Score }\end{array}$ & $\begin{array}{l}\checkmark \\
\checkmark\end{array}$ & $\checkmark$ & $\checkmark$ & $\checkmark$ & $\checkmark$ & \\
\hline Program Controls & $\checkmark$ & $\checkmark$ & $\checkmark$ & $\checkmark$ & $\checkmark$ & $\checkmark$ \\
\hline Program FE & $\checkmark$ & $\checkmark$ & $\checkmark$ & $\checkmark$ & $\checkmark$ & $\checkmark$ \\
\hline Year FE & $\checkmark$ & $\checkmark$ & $\checkmark$ & $\checkmark$ & $\checkmark$ & $\checkmark$ \\
\hline State Trend & $\checkmark$ & $\checkmark$ & $\checkmark$ & $\checkmark$ & $\checkmark$ & $\checkmark$ \\
\hline
\end{tabular}

Note: ***: significant at $1 \%$ level; **: significant at $5 \%$ level; *: significant at $10 \%$ level. This table reports the effects of adopting SISU on different dependent variables. In Columns (1) and (2), the dependent variable is an indicator variable for whether student's enrollment status is on leave or cancellation. In Column (3), the dependent variable is a dummy variable for whether student's enrollment status is on leave, while Column (4) refers to cancellation only. Column (5) excludes individuals who requested cancellation and the dependent variable is defined as an indicator for whether student's enrollment status is on leave. Column (6) reports the effects of SISU on the 1 minus the ratio between the number of enrolled students by the end of first year and the number of seats. In all specifications, program covariates (number of seats), program and year fixed effects, and state trends are included. We include ENEM scores in Column (1). We also add students' characteristics in Columns (1)-(5). Robust standard errors clustered at institution level are reported in parenthesis. Sources: Higher Education Censuses and ENEM microdata. 


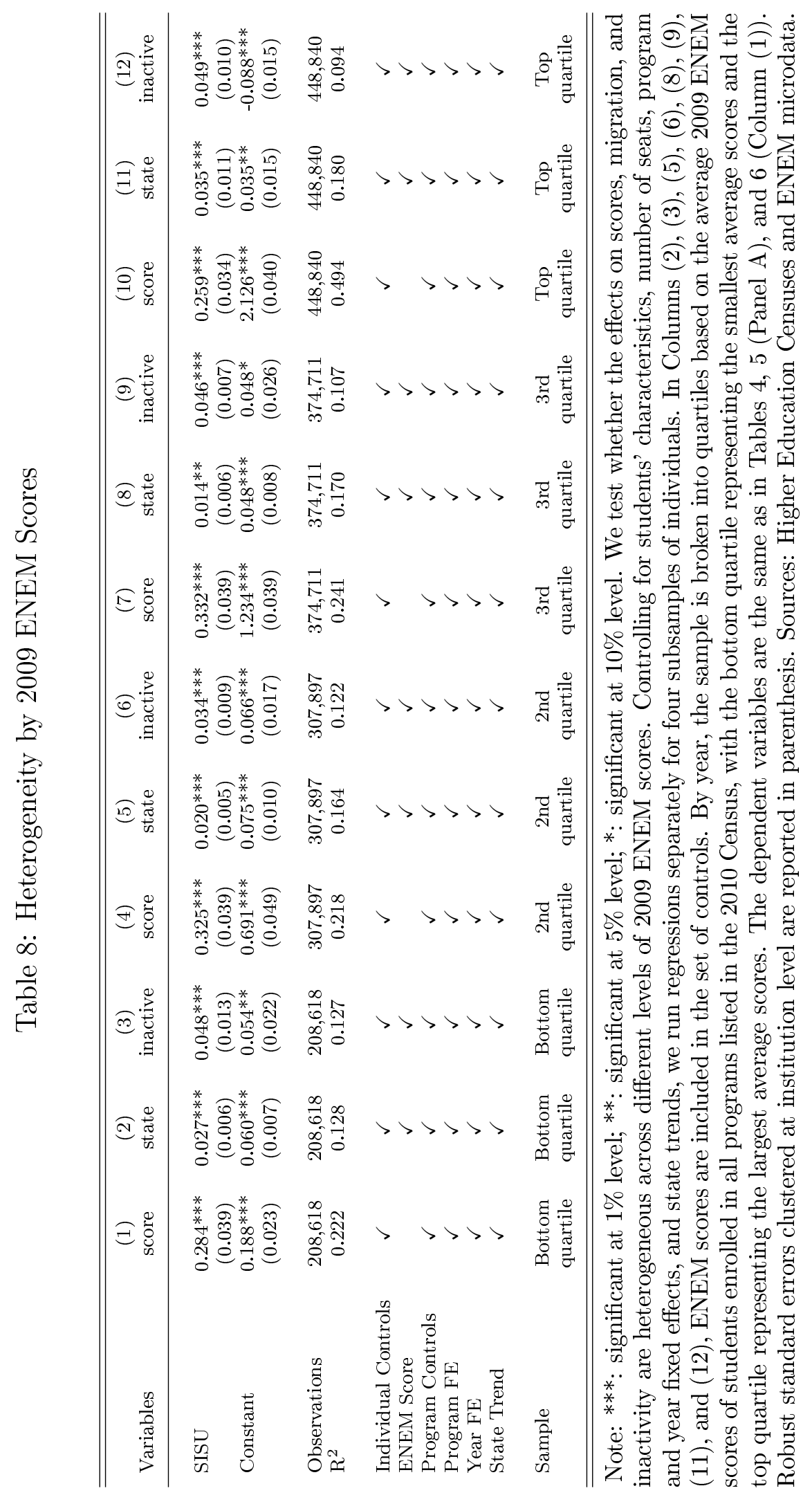




\section{APPENDIX}

\section{Appendix I - SISU Application and Admission}

Applicants have to take the ENEM exam to register in the SISU system. Online registration for ENEM typically takes place in May, and the registration fee costs 68 reais in 2016 (approximately 20 USD). Payment exemption is automatically given to all students graduating from public high schools. It is also allowed in two other cases: for students who have had their entire high school education either in public high schools or in private high schools under full scholarship and have per capita monthly family income lower than 1.5 minimum wage; and for students whose families have per capita monthly income lower than half of the minimum wage or total family income lower than 3 minimum wages.

The new ENEM exam is a two-day test and consists of a written essay and 180 multiplechoice questions, divided into four knowledge areas: Math, Natural Science, Human Science, and Language and Code. In comparison to the older version (whose subjects were: Biology, Chemistry, Geography, History, Math, Physics, and Portuguese), the new exam comprises a wider range of subjects: Human Science (Geography, History, Philosophy, and Sociology), Language and Codes (Foreign Language, Literature, and Portuguese), Math (Geometry and Math), and Natural Science (Biology, Chemistry, and Physics). All applicants take the ENEM exam on the same weekend, typically in late October or early November.

They receive their ENEM scores in January. A few days later, the SISU online platform opens. Applicants subscribe to the system by submitting their ENEM subscription number. There is no monetary cost to subscribe to SISU. All applicants have four (or five, depending on the rules previously set by the Ministry of Education) days to submit a list of up to two options of career-institution (program) pair and decide whether they will compete for the quota seats.

Students' scores are calculated according to different weights given to each of the five knowledge areas (Math, Natural Science, Languages and Codes, Human Science, and Writing Essay). Each institution is free to determine a combination of weights for each program. Thus, students' scores might widely vary across these career-institution combinations.

During the registration period, when the system is open, the cutoff scores for each program are calculated at the end of each day, and this information is provided to all subscribers. The partial classification for each subscriber is also privately disclosed. Students can change 
their options over the registration period as many times as they wish, but only the last confirmed choice is valid.

Figure 2 illustrates how an applicant can indicate up to two choices of career and institution combinations, and specify whether he prefers to compete for seats reserved for affirmative action policies. It is possible to notice different composite scores given to the same applicant because he chooses different careers at the same institution. Figure 3 presents the partial classification and the cutoff score for each chosen option. Figure 4 indicates that the system allows an applicant to modify his assignments as many times as he wishes until the deadline. Figure 5 shows that an applicant can search for other majors and institutions and also check the last updated cutoff.

When the registration period ends, students are assigned to programs through a variant of a deferred acceptance algorithm. The algorithm works in the following way: each candidate proposes his first choice. After ranking the applicants by their composite score, each program rejects the lowest-ranking students in excess of the pre-specified number of available spots, and the remaining applicants are tentatively admitted. The applicants rejected in their first alternative apply to the next most preferred program from their list. Thus, each program considers these new applicants and the tentatively admitted applicants, and assigns its spots to these candidates, following a priority order. The lowest-ranking students in excess of the number of available seats are rejected.

At least one call is announced. The number of calls is previously set up for each edition; for example, in January of 2015, SISU had a single call. During the call period, the applicants who ranked and qualified for their assigned option can enroll in the program. Regardless of having enrolled in his first option, if the applicant is qualified for his top choice, he cannot participate in the next call. Also, regardless of whether he has enrolled in his second alternative, the applicant still runs to his first option in the next call when he qualifies for his second choice, but not for his first choice. After regular calls, students who did not qualify for their options should inform the system if they wish to be included on a waitlist. In this case, only the first option is considered. Thereafter, SISU provides to institutions a waitlist for each program and the progress is similar to Vestibular. Any remaining spot is filled based on a waitlist, following the ranking of applicants. 
Figure 2: An Example of Choices from the SISU System

Figure 3: An Example of Partial Classification and Cutoff Scores

Figure 4: An Example of an Applicant Modifying his Options

Figure 5: An Example of an Applicant Searching for Other Options and Checking the Last Updated Cutoff 


\section{Appendix II - Evolution of SISU}

Figure 6: Evolution of SISU (In Number of Institutions)

Figure 7: Evolution of SISU (In Number of Spots) 


\section{Appendix III - Data Appendix}

This appendix contains a detailed description of the data used in this paper.

\subsection{Higher Education Census}

\subsubsection{General Information:}

The Higher Education Census has been carried out annually by the National Institution for Educational Studies and Research (INEP) since 1995. Microdata at the student level is only available from 2009 onward. Information on each academic year $t$ (which corresponds to a calendar year) is collected in year $t+1 .{ }^{35}$ The Census contains detailed information on all higher institutions, programs, and students enrolled at any time over year $t$. Reporting is compulsory for all institutions by law. Reporting is also a requirement for many initiatives sponsored by the Ministry of Education, such as research grants and fellowships, and, most importantly, for being issued a credential that allows institutions to operate in the educational market.

Unique identification numbers - the Brazilian Taxpayer Registry (Cadastro de Pessoa Física, or $C P F)$ - are not reported in 2009. Thus, the 2009 Census cannot be linked to the 2008 ENEM microdata through CPF. In addition, INEP staff discouraged us from linking both datasets because the 2009 Census was the first in which student-level data were collected. Therefore, our sample analysis is restricted to the 2010-2014 Higher Education Censuses.

\subsubsection{The Brazilian Higher Education Structure:}

The Brazilian higher education structure is divided into six administrative categories: special $^{36}$, for-profit private, non-profit private, federal public, state public, and municipal public institutions. Table 10 shows how institutions are distributed by administrative categories, while Table 11 depicts the total number of students in each category over the 20102014 period.

\footnotetext{
${ }^{35}$ Data are collected online, through a platform called Censup, and reported by each higher education institution. The system opens from February to May. Data checks are performed by INEP when the system closes. Inconsistencies are communicated to institutions, which in turn submit a final round of edits.

${ }^{36}$ Special institution is a category created in 2012 and refers to institutions created by municipal or state law before the enactment of the Federal Constitution in 1998. Those institutions, however, are not predominantly funded with public resources and are not tuition-free.
} 
Table 10: Total Number of Institutions by Administrative Categories

\begin{tabular}{lccccc}
\hline \hline Category & 2010 & 2011 & 2012 & 2013 & 2014 \\
\hline Federal Public & 99 & 103 & 103 & 106 & 107 \\
State Public & 108 & 110 & 116 & 119 & 118 \\
Municipal Public & 71 & 71 & 65 & 54 & 49 \\
For-Profit Private & 951 & 975 & 989 & 991 & 998 \\
Non-Profit Private & 1149 & 1106 & 1123 & 1099 & 1072 \\
Special & - & - & 20 & 22 & 24 \\
\hline Total & 2378 & 2365 & 2416 & 2391 & 2368 \\
\hline \hline
\end{tabular}

Source: 2010-2014 Higher Education Censuses.

Note: the graph refers to the number of spots offered by SISU. Data is from MEC's announcements. The axis on the left refers to the number of available spots for each year, while the axis on the right refers to the ratio between the number of spots offered by SISU and the number of institutions that adopt the system. In all, 64,486, 109,461, 139,100, 169,043, and 223,168 spots were offered in 2010, 2011, 2012, 2013, and 2014, respectively.

Table 11: Total Number of Students by Administrative Categories

\begin{tabular}{lcccccc}
\hline \hline Category & 2010 & 2011 & 2012 & 2013 & 2014 & Total \\
\hline Federal Public & 1.159 .627 & 1.249 .778 & 1.352 .632 & 1.422 .513 & 1.504 .383 & 6.688 .933 \\
State Public & 698.167 & 730.024 & 745.846 & 735.991 & 743.425 & 3.653 .453 \\
Municipal Public & 128.191 & 152.405 & 75.758 & 72.081 & 62.414 & 490.849 \\
For-Profit Private & 2.697 .869 & 3.026 .210 & 3.569 .232 & 3.854 .182 & 4.514 .593 & 17.662 .086 \\
Non-Profit Private & 3.653 .365 & 3.803 .307 & 3.663 .894 & 3.676 .742 & 3.824 .023 & 18.621 .331 \\
Special & - & - & 158.121 & 167.780 & 145.097 & 470.998 \\
\hline Total & 8.337 .219 & 8.961 .724 & 9.565 .483 & 9.929 .289 & 10.793 .935 & 47.587 .650 \\
\hline \hline
\end{tabular}

Source: 2010-2014 Higher Education Censuses.

\subsubsection{Sample Restriction:}

We make several restrictions to the sample. First, the sample is restricted to first-year students because we are interested in short-term effects. Second-year and more advanced students that appear in a given institution do not include those who have dropped out in their first year (and therefore are no longer linked to this institution in their second year), but include transfers from other institutions. Eliminating first-year students reduces the sample from 47,587,650 to 13,181,708 observations (more precisely, 2,196,822 in 2010, 2,359,409 
in $2011,2,756,773$ in 2012, 2,749,803 in 2013, and 3,118,901 in 2014). Second, we exclude municipal public, non-profit private, for-profit private, and special institutions from the sample because only public and tuition-free institutions can participate in the SISU platform. Thus, data from federal and state public institutions are maintained. The sample shrinks from 13,181,708 to 2,473,382 observations (among these observations, 1,619,449 individuals are found in federal public institutions (302,380 in 2010, 308,537 in 2011, 334,246 in 2012, 325,294 in 2013, and 348,992 in 2014), while 733,852 students are part of state public institutions (141,413 in 2010, 146,170 in 2011, 152,724 in 2012, 142,962 in 2013, and 150,583 in 2014)). Third, we exclude online education programs, leading to a sample of 2,167,313 students (among these observations, 1,464,531 individuals are found in federal public institutions $(269,237$ in 2010, 282,040 in 2011, 300,487 in 2012, 299,230 in 2013, and 313,537 in 2014), while 702,782 students are part of state public institutions (134,932 in 2010, 139,111 in $2011,144,932$ in $2012,139,744$ in 2013 , and 144,063 in 2014)). We refer to this sample as the Census baseline sample.

\subsubsection{Variable Construction:}

Student-level information includes (the variables are represented in bold):

Gender, Age and Disability. These variables are directly constructed from the Census (the original names are: IN_SEXO_ALUNO, NU_IDADE_ALUNO, and IN_ALUNO_DEFICIENCIA) to inform whether the student is female, student's age, and whether the student has any type of disability, respectively.

Socioeconomic Status. Affirmative action policies are directed to students from low income families, from certain ethnic groups, from public schools, and disabled students. We identify students benefiting from the quota policy if they occupy seats reserved for lowincome students (the original variable is IN_RESERVA_RENDA_FAMILIAR), black, mulattos, or Indian students (IN_RESERVA_ETNICO), disabled students (IN_RESERVA_DEFICIENCIA), and/or students who have attended public schools (IN_RESERVA_ENSINO_PUBLICO). In addition, we build a measure of whether the student receives any type of social support (e.g., housing support, food support, material support, etc.) from the institution (IN_APOIO_SOCIAL). We also create an indicator variable for whether the student is white (CO_COR_RACA_ALUNO) to summarize in- 
formation on race.

Enrollment Status. Students' enrollment status in a current year (CO_SITUACAO) falls into one of the six categories: currently enrolled (cursando), leave of absence (matrícula trancada), withdrawal/cancellation (desvinculado do curso), transferred to a new degree in the same institution (transferido para outro curso da mesma IES), graduated (formado), or deceased (falecido). To capture changes in enrollment status in the first year of college after initial matriculation, we create an indicator variable of whether the student requests leave of absence or cancellation. This variable does not consider transfer to a new degree in the same institution because transfer rules are very strict for first-year students. Also, graduated students are not expected in our sample of first-year students. The group of inactive students is comprised of students whose enrollment status is either leave of absence or withdrawal.

Admission Procedure. The Census provides information on entrance procedures for each student: admission through ENEM (the original variable is IN_ING_ENEM), admission through Vestibular (the original variable is IN_ING_VESTIBULAR) or other admission criteria.

Migration. We describe how we construct the main measure of mobility later. We now explain how we construct an alternative measure for migration to check the robustness of our results: an indicator variable of whether the student's birthplace is different from her current location. Information on students' current location comes from program-level data, whereas information on students' birthplaces are determined from student-level data. We then define interstate (or intermunicipality) mobility as an indicator variable of whether the state (or municipality) of birth is different from the state (or municipality) where the student attended college (namely, municipality birthplace (or state birthplace)). Because students' birthplace is directly informed by institutions, many observations present missing information. Nearly 70 percent of students (more precisely, 1,517,614 out of 2,167,313 observations) have information on place of birth.

Regarding the program (institution) covariates, the following variables are constructed:

Number of Spots. This variable is directly reported by institutions and is available at the program-level data. When no spots are reported (probably by mistake), we consider the total number of first-year students as a proxy for the number of spots. 
Number of Programs. The total number of programs for each institution is constructed from the program-level data.

Number of Instructors. The total number of instructors for each institution is directly built from the faculty-level data. We only consider active, as well partial or full-time instructors.

We explain how we construct the minor variables from Table 2:

Location. Institution-level data provide information on where the institution is located. We create an indicator variable (located in state capital cities) of whether an institution is based on a state capital city (the original variable is IN_CAPITAL). We also construct indicator variables for each region where an institution is located. Brazil is divided into five regions, thus five indicator variables are created (located in Central-West region, located in North region, located in Northeast region, located in Southeast region, and located in South region).

Size. We include measures for institutions' size. The total number of technical-administrative employees (number of employess) is directly collected from the Census (the original variable is QT_TEC_TOTAL). The total number of programs, number of students and number of teachers are constructed from the program-, student- and teacher-level data, respectively.

Other characteristics. Creating an indicator variable for federal institutions is straightforward (the original variable is CO_CATEGORIA_ADMINISTRATIVA). We further construct an indicator variable (university institutions) of whether an institution is a university organization (CO_ORGANIZACAO_ACADEMICA), as well as an indicator variable (institutions have a lab) of whether an institution is equipped with a lab (IN_UTILIZA_LABORATORIO).

\subsection{ENEM Microdata}

The ENEM microdata is also annually gathered by INEP. Reporting to the Brazilian Taxpayer Registry (CPF) is mandatory to register and take the ENEM exam. In this project, we use confidential data to link ENEM microdata to the Higher Education Census through 
$\mathrm{CPF}$, which is also compulsorily reported in the Census datasets. To our knowledge, we are the first researchers to have access to these confidential sources.

Firstly, we standardize ENEM scores, which are the average of five areas of knowledge (Natural Science, Math, Human Science, Languages and Codes, and Writing Essay) for all ENEM test-takers by year.

Using CPF as the unique student identification number, we then link five cohorts of firstyear students from the Census to the ENEM microdata. That is, the 2010 Census is matched to the 2009 ENEM data (58.82 percent of the first-year sample is matched), the 2011 Census to the 2010 ENEM data (69.74 percent), the 2012 Census to the 2011 ENEM data (71.81 percent), the 2013 Census to the 2012 ENEM data (76.25 percent), the 2014 Census to the 2013 ENEM data (77.14 percent). Overall, we are able to combine approximately 71 percent of college first-year to ENEM datasets (1,539,008 out of 2,167,313 students). We refer this sample as the Census-ENEM matched sample.

We notice relatively lower matching for the 2010 Census. It can be explained by the episode of leaked questions, which led to the postponement of the exam. Instead of taking place in November of 2010, the 2009 ENEM exam was rescheduled for December of 2010. Thus, the absence rate from this edition was higher than the average of previous years.

Our main variable for mobility is constructed from this Census-ENEM matched sample. We define the interstate (or intermunicipality) mobility as an indicator variable of whether the state (or municipality) where the student resided when he took the ENEM exam is different from the state (or municipality) where the student attended college (namely, municipality (or state)).

Our minor data source is a list of programs and institutions available in the SISU system since its inception. Years of adoption are also included in the list, which was provided by the Ministry of Education. Although the system opens twice a year, the Census data is annual. To deal with this inconsistency, we group the SISU adoption by year. We coded all programs and institutions to combine them with the Census. 


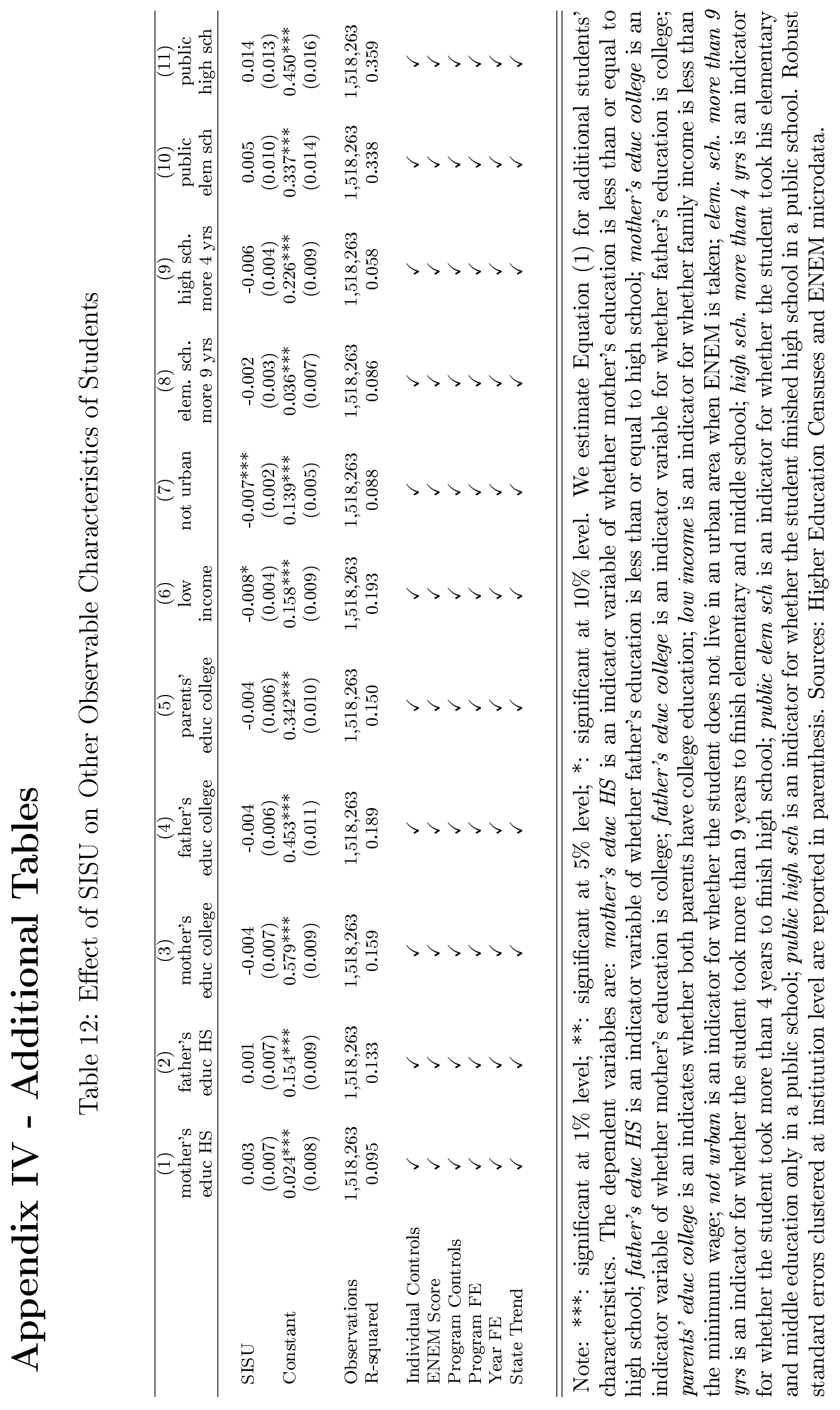

